\title{
¿Puede la tortura estar moralmente justificada en algún caso?
}

\author{
Juan Antonio García Amado*
}

\section{Resumen}

Con fundamento en la distinción entre juicios morales y jurídicos, el autor defiende la tesis de que la tortura, en ciertos casos, puede estar moralmente permitida. En consecuencia, se ubica en el bando de quienes se muestran contrarios a la posición de los absolutistas morales que no admiten en ningún caso y bajo ninguna consideración la posibilidad de la tortura. Por esto, en el texto se defiende que bajo situaciones particulares y desde una perspectiva moral, no es descartable que la tortura esté permitida. Ahora bien, ello ni puede significar una defensa a permitir jurídicamente la tortura, ni mucho menos avalar o no condenar ni mostrar el más absoluto rechazo a las torturas aplicadas en diferentes momentos por parte de diferentes gobiernos 0 cuerpos de seguridad.

\section{Palabras clave}

Tortura. Absolutismo moral. Consecuencialismo. 


\section{Abstract}

Based on the distinction between moral and legal judgments, the author supports the thesis that torture, in some cases, can be morally permissible. Consequently, it is located on the side of those who are opposed to the moral absolutist position that does not endorse in any case and under any consideration the possibility of torture. Therefore, in the text it is argued that under particular situations and from a moral perspective, it is not ruled out that torture is permitted. However, this does not mean a defense can legally permit torture, much less validate or not condemn or show the most absolute rejection of torture applied at different times by different governments or security forces

\section{Keywords}

Torture. moral absolutism. Consequentialism.

\section{Sumario}

1. Planteamiento y matices. 2. ¿Hay absolutos morales? 3. Humanidad e inhumanidad. 4. ¿Y la legítima defensa? 5. Conclusión provisional y aviso definitivo. 6. Sobre las posibles consecuencias penales para el torturador cuando la tortura puede estar moralmente justificada. 7. El ejemplo de la bomba de relojería y sus críticos. 7.1. Sobre las condiciones epistémicas de los casos. 7.2. Sobre los límites y problemas del consecuencialismo moral. 7.3. Sobre las intenciones de los tratadistas. 7.4. Sobre un peculiar enfoque consecuencialista. 7.5. Quizá haya una eximente, pero no hay una justificación. 7.6. "Moral luck". 7.7. La bomba puede acabar estallando de todos modos. 


\section{Planteamiento y matices}

En este escrito voy a defender que no es racionalmente descartable que la tortura pueda estar en algún caso moralmente permitida, permitida por una moral que se pretenda racional e intersubjetivamente aceptable. De inmediato harán saltar las alarmas los guardianes del templo de la corrección política y los que piensan que la ciencia debe ser sensible a los tabúes y amiga de la censura ajena y la autocensura. Así que me apresuro a declarar seria y rotundamente varias cosas, antes de echar a andar con los argumentos sobre el tema:

a) No soy partidario de la legalización de la tortura absolutamente en ningún caso. Por consiguiente, en tal punto nada tengo que ver con autores como Dershowitz o Brugger.

b) No se me hace raro, para nada, pensar en supuestos en los cuales una acción puede considerarse moralmente permitida y, al mismo tiempo, pensarse que debe estar jurídicamente prohibida (prohibida por un sistema jurídico que consideramos legítimo y razonablemente justo) y que deben ser por el Derecho castigados los que la realicen. Esto se ha dicho muchas veces respecto de actos de desobediencia civil. Pero podrían traerse muchos ejemplos. Puede haber muy buenas razones tanto para que el Derecho no castigue conductas razonablemente consideradas inmorales como para que castigue otras razonablemente juzgadas como morales. Todo ello es independiente de cómo, además, jueguen en el sistema jurídico-penal las llamadas causas de justificación, sean eximentes o sean atenuantes.

c) El objeto de crítica en este trabajo es la tesis que mantiene que la prohibición moral de la tortura es radical y absoluta y que no admite excepciones en ningún caso posible, ni realmente acontecido ni imaginable. Los críticos de esa tesis absoluta aducimos que, al menos en hipótesis, puede haber algún caso en que sea razonable juzgar que la tortura puede estar moralmente permitida. Pero no nos limitamos a esa afirmación general, pues ello supondría una habilitación genérica para los torturadores, equivaldría a mantener que son ellos o sus jefes políticos 0 administrativos los que en cada oportunidad deben prudencialmente decidir si moralmente deben o no deben torturar. Una postura así no es hoy en día mantenida por casi nadie en el gremio de la teoría moral o jurídica. Lo que se hace es acotar unas condiciones hipotéticas y muy precisas, bajo las cuales (y solo bajo las cuales) moralmente cabría, como excepción, la tortura. Por tanto, los que así razonamos ni somos ni nos queremos cómplices de ningún caso real e histórico de tortura en el que no hayan concurrido esas condiciones justificadoras. En otras palabras, se puede ser un antiabsolutista en esta materia y, al mismo tiempo, un radical y apasionado 
crítico de lo que se hizo en las cárceles de la dictadura franquista, argentina, chilena, stalinista, camboyana, hitleriana, etc., o en las también infames prisiones de Abu Ghraib, entre otros muchos lugares en los que se ha escrito tanto capítulo de la historia universal de la infamia.

Si alguien se pregunta, sin más, si puede en alguna ocasión estar permitida la tortura ${ }^{1}$ incurre en ambigüedad normativa. Es como si nos preguntáramos si puede estar permitido matar a otras personas en algún caso. Hay que especificar y concretar bastante. En primer lugar, deberíamos aclarar en qué ámbito normativo nos movemos. Por ejemplo, algo puede estar o considerarse prohibido por el derecho y permitido por la moral o por determinado sistema moral. En segundo lugar, y sea el sistema normativo que sea, algo puede estar o considerarse prohibido como regla general y existir, sin embargo, en ese sistema normativo de referencia, una lista más o menos larga de excepciones a tal prohibición. Es lo que pasa en nuestros sistemas jurídicos con la prohibición legal de matar a otras personas. En tercer lugar, y sin ánimo de agotar la enumeración de ambigüedades o indeterminaciones que habría que ir recortando, importa ver qué tipos de acciones son las que están referidas por o encajan bajo la referencia de la correspondiente norma prohibitiva; concretamente, se trata de preguntarse si dicha norma alude a acciones efectivas o si abarca también omisiones ${ }^{2}$. Evidentemente, no entraré aquí en todas las cuestiones, trataré nada más el tema de si lo más razonable es ver como absoluta la prohibición moral de la tortura.

Para ir calentando motores, juguemos con un ejemplo rebuscado e inventado. Por alguna razón científica difícil de explicar y que aquí vamos a asumir como indiscutible, el individuo S puede viajar al pasado una sola vez y alterar el curso de la

1 No voy a entrar en los problemas conceptuales o de definición de lo que se deba o se pueda entender por tortura. Para un tratamiento interesante de esos problemas remito, entre muchos, a F.M. KAMM, Ethics for Enemies. Terror, Torture and War, New York, Oxford University Press, 2011, pp. 5ss; y a J. J. Wisnewski, R.D. Emerick, The Ethics of Torture, London/New York, Continuum, 2009, 1-15.

2 Pongamos un ejemplo de eso último. Imaginemos que hay un sujeto al que yo no quiero nada y que me interesa (legítima o ilegítimamente) que confiese algo. Por ejemplo, yo soy un policía, he detenido a quien sé que ha secuestrado a una persona que se encuentra seguramente en grave peligro de muerte y quiero que lo antes posible me diga dónde dejó encerrada a esa persona que secuestró. Asumamos que me está prohibido torturar a ese sujeto. Pero resulta que mientras yo lo perseguía para detenerlo, él sufrió un accidente con su coche. Cuando yo llego a su altura, veo que en distintas partes de su cuerpo se le han clavado unos hierros que le causan muchísimo dolor y que pueden acabar matándolo. Yo puedo, sin mucho esfuerzo y sin riesgo adicional para él, librarlo de esos hierros que lo "torturan" o puedo llamar para pedir auxilio médico, pero le digo que no haré lo uno ni lo otro mientras no me diga dónde guardó al secuestrado, y así pasamos quince o veinte minutos. ¿Lo estuve torturando por omisión? Sabemos que, desde el punto de vista jurídico, mi conducta puede encajar en el tipo de algún otro delito. Pero la pregunta sigue siendo: ¿jurídicamente vulneré la prohibición de tortura? ¿Y la prohibición moral de torturar? 
historia. Pero no elige él a dónde va, le viene dado. Le toca ir a Alemania a principios de los años treinta y tiene la posibilidad de matar a Hitler. Si mata a Hitler, no habrá ni segunda guerra mundial ni holocausto judío ni ninguno de tantos desastres provocados por aquel ser degenerado y sus secuaces. $S$ aparece cerca de Hitler y lleva en su mano una pistola cargada y en perfecto funcionamiento. Sólo tienen unos segundos para decidirse. Puede matarlo y de inmediato desaparecerá de allí, no hay riesgo para $S$. ¿Creemos que debería matar a Hitler o que no? Pero ese no era propiamente nuestro tema. Así que añadámosle más picante al ejemplo y lleguemos a lo de la tortura. S ha caído cerca de Hitler, sabe que Hitler está escondido por los alrededores, pero se da cuenta $S$ de que no tendrá tiempo para dar con él, ya que nada más que dispone de una hora y luego retornará aquí, a nuestro presente. Se encuentra a Goebbels, que es el único que sabe dónde se halla escondido el otro. $S$ puede torturar a Goebbels para que "cante" y seguramente revelará el paradero de Hitler si lo tortura. ¿Nos parece que estaría justificado que primero torturara a Goebbels y luego matara a Hitler?

Realmente no sé cuáles son las respuestas más razonables o que mejor se pueden fundamentar. Lo que sí creo es que algunas reacciones habituales no me merecen muy seria consideración, por superficiales y porque son tópicos que valen nada más que para escurrir el bulto refugiándose en lo trillado. Pongo solo un ejemplo. Me imagino a más de cuatro alegando, sonrojados y pletóricos, que si S mata a Hitler o tortura a Goebbels, se convierte en uno más como ellos, se equipara moralmente a los asesinos y tal y cual. Pues no. Porque es muy difícil dar veredictos genéricos y quedarse tan ancho. Por aquella regla de tres, tampoco $S$ podría matar a Hitler 0 torturar a Goebbels si esa era la única manera para salvar a un hijo suyo que iba a ser ejecutado por ellos en ese momento; o no cabría la legítima defensa y, curioso, no cabría precisamente frente a los más malvados, para no igualarse a ellos. Además, y sobre todo, la situación que he pergeñado para $S$ es muy peculiar y se las trae: si él no mata a Hitler (y no tortura a Goebbels para poder matar a Hitler), los muertos que no ha salvado (los que Hitler y sus acólitos matarán, más los que fallecen en la Segunda Guerra Mundial...) serán sesenta o setenta millones. S no evitó la muerte de sesenta millones de personas para no sentirse tan malo como Hitler o Goebbels o para que no sentenciemos desde nuestras cátedras que acabó equiparándose a aquellos al decidir matarlos y torturarlos. Yo diría que algo falla y que, sostengamos una cosa u otra, hay que afinar mucho más si queremos ser serios.

\section{2. ¿Hay absolutos morales?}

El asunto, está en si hay absolutos morales. Antes que nada, permítaseme una aclaración sobre a qué nos referimos cuando hablamos de absoluto morales 
y qué distinciones hay que considerar ahí. Empecemos con unas palabras de un muy afamado y prestigioso iusfilósofo católico y iusnaturalista, John Finnis. Explica que "en el sentido relevante de "absoluto», hay muchas normas morales que son verdaderas, pero no absolutas: "Alimenta a tus hijos», por ejemplo. Esta norma moral es verdadera, forzosamente, pero no absoluta. Cuando el único alimento disponible es el cuerpo vivo del niño de tu vecino, uno no puede (moralmente) aplicar esa norma en su propia acción; ni cabe violarla por no aplicarla"3. Y aclara que "las normas morales absolutas muestran la siguiente característica: los tipos de acción que especifican son especificables, como objetos potenciales de elección, sin depender de término evaluativo alguno que presuponga un juicio moral sobre la acción. Sin embargo, esta especificación no estimativa hace posible que la reflexión moral juzgue que la elección de tal acto ha de ser excluida de nuestra deliberación y de nuestra acción"4. A título de ejemplos de esas "normas morales que no presentan excepciones", menciona Finnis las siguientes: "No sólo aquellos abortos que son elegidos como medios para algún fin insuficientemente importante, sino toda muerte de niños no nacidos como medio para un fin. No sólo la fabricación de niños para propósitos frívolos o egoístas, sin todas las decisiones de generar niños de forma artificial, en vez de mediante la unión sexual. No solamente el adulterio en el sentido de comercio extramarital de (o con) persona casada que descuida el bien del matrimonio, sino el adulterio tal como el término fue usado en la tradición judía y cristiana: comercio extramarital de (o con) una persona casada, sin más"5. $Y$ después de regalar esos ejemplos de normas morales absolutas, insiste: llamar a esas normas absolutas "es decir tan sólo que carecen de excepciones" ${ }^{\text {. }}$. Claro que desde el punto de vista fáctico o lógico son posibles excepciones, "pero están moralmente excluidas". "Una norma que carece de excepciones es una norma que nos dice que siempre que llevamos a cabo una elección, nunca debemos escoger hacer esa clase de cosas"7.

El deontologismo de Finnis, de base religiosa, no admite en ningún caso una justificación basada en consecuencias; el mal "no debe ser escogido para que el bien

3 John Finnis, Absolutos morales, Barcelona, Ediciones Internacionales Universitarias, 1991, trad. de J.J. García Norro, p. 15.

$4 \quad$ Ibid., p. 16.

5 Ibid., p. 16

$6 \quad$ Ibid., p. 16.

7 Ibid., p. 17. 
pueda venir"8. Y, cómo no, cita Finnis el Evangelio de San Juan: "¿No es mejor que muera un inocente a que perezca un pueblo entero?". Contesta que no9

Decimos que la prohibición moral de $X$ es absoluta 0 que hay un absoluto moral que prohíbe hacer $X$ cuando el hacer libremente $X$ (pudiendo optar por no hacer $\mathrm{X}$ ) se considera moralmente reprochable, moralmente malo, en todo caso y bajo cualesquiera circunstancias posibles. En palabras de Judith Jarvis Thomson, "Ios absolutistas mantienen que ciertos actos (por ejemplo, la agresión a un inocente, el romper una promesa, el robar, el mentir) son siempre inmorales [wrongs], incluso cuando sirven para evitar los más extremos desastres"10.

Fijémonos en que una prohibición moral absoluta también puede describirse como aquella que versa sobre una acción (consciente y deliberada, una acción de la que el sujeto es moralmente responsable) para la que, como tal, no son admisibles excusas morales. Es decir, si la acción es propiamente una acción responsable del sujeto (o sea, si hay excusas, las hay para quitar de la acción su carácter de acción responsable; por ejemplo, porque ese sujeto actuaba bajo coacción invencible, bajo miedo insuperable, bajo alguna grave alteración mental, etc.), nada puede disculparla, nada puede eliminar el reproche moral para el autor por haber realizado esa acción. Así, si para la tortura rige una prohibición moral absoluta, no excusará moralmente al torturador el que su acción haya sido para salvar la vida de un hijo suyo o para salvar la vida de mil conciudadanos, como en el caso típico de la bomba de relojería, del que luego hablaremos.

No debemos confundir lo moral y lo jurídico. El derecho puede brindar razones atenuantes 0 absolutorias en lo jurídico, razones que libran de la sanción 0 responsabilidad jurídica, aun en el caso de que la acción sea moralmente reprochable 0 aunque esa acción infrinja una prohibición moral absoluta. El derecho y la moral, al menos en la modernidad, son sistemas normativos distintos y perfectamente

\footnotetext{
$8 \quad$ Ibid., p. 60.

$9 \quad$ Ibid., p. 62.

10 Judith Jarvis Thomson, "Killing, Letting Die, and the Trolley Problem", en Russ Schafer-Landau (ed.), Ethical Theory. An Anthology, Blackwell, $2^{\mathrm{a}}$ ed., 2013, p. 437. Ese artículo fue originariamente publicado en 1976, en el número 59 de The Monist, pp. 204-217). Alguna cita más. Pierre Blackburn, refiriéndose al absolutismo moral de la Iglesia católica, basado en la idea de ley natural, dice así: "Por absolutismo entendemos el hecho de que para la Iglesia católica ciertas categorías de acciones están prohibidas, sin importar las circunstancias. Ninguna circunstancia puede justificar el asesinato, el robo o (...) la anticoncepción artificial. Tales acciones no pueden ser nunca justificadas, sean las que sean las circunstancias, aun si se trata de elegir un mal menor" (P. BLACKBURN, La ética. Fundamentos y problemáticas contemporáneas, México, Fondo de Cultura Económica, trad. d J.J. Utrilla Trejo, 2006, pp. 156-157).
} 
diferenciados y ni todo lo jurídico es moral, ni todo lo moral es jurídico, ni todo lo antijurídico es inmoral, ni todo lo inmoral es antijurídico. Caben y se dan todas las combinaciones.

Cuando en estos asuntos hablamos de derecho, pensamos en sanciones, penales ante todo, aunque no solo. Nos encaja bien en los esquemas habituales que una conducta no moralmente reprochable no sea castigada o que una conducta que moralmente es fuertemente reprochable (y que, además, afecta a bienes ajenos 0 bienes generales) sí reciba castigo jurídico. Por eso comulgamos de buen grado con la eximente penal de legítima defensa, por ejemplo, o con determinadas agravantes, como la de ensañamiento. Lo que nos inquieta más es que pueda haber acciones que moralmente se consideren admisibles, o incluso debidas, y que, no obstante, reciban castigo según el derecho. Esto es lo que puede ocurrir si la prohibición moral de la tortura no se ve como absoluta, ya que la prohibición jurídica de la tortura sí es absoluta y radical"1. 0, como dice Henry Shue, en su ya clásico ensayo "Torture", de 1978, "La tortura se opone completamente al derecho internacional, incluido el derecho de la guerra. Ninguna otra práctica, salvo la esclavitud, es tan universal y unánimemente condenada por el Derecho y por las convenciones humanas"12. Si ambas prohibiciones, la moral y la jurídica, son absolutas, la correspondencia es tranquilizadora. Si la prohibición moral no lo es, nuestra duda será esta: ipuede estar justificado que el derecho jurídicamente descalifique y castigue las torturas que moralmente están justificadas?

Podemos nosotros, pues, diferenciar dos cuestiones, después de dar por sentado que la prohibición de tortura es radical en el derecho internacional y en el derecho interno de la inmensa mayoría de los estados. La primera cuestión es la de si desde el punto de vista moral es o no razonable una prohibición absoluta de la tortura, de modo que en cualquier caso la acción de torturar puede y debe considerarse inmoral sin paliativos. La segunda cuestión es la de si estimamos que, sea cual sea la mejor respuesta a la pregunta anterior, hay buenas y definitivas razones para conservar la prohibición jurídica absoluta de la tortura y, por tanto, para declarar la ilicitud jurídica de la misma en cualquier caso imaginable, así como el castigo de los torturadores cuando concurran los demás requisitos jurídicos para ello.

11 Como recuerda Sanford Levinson en su introducción al volumen Torture. A Collection (Oxford University Press, 2004), por él editado, "la tortura está inequívoca y absolutamente prohibida por el derecho de todas las naciones civilizadas (incluyendo los Estados Unidos)" (SAnford Levinson, "Contemplating Torture. An Introduction", p. 23).

12 Henry Shue, "Torture", recogido en Sanford Levinson (ed.), Torture. A Collection, Oxford University Press, 2004, p. 47. El original de H. Shue se publicó en 1978, en el número 4 de Philosophy \&Public Affairs, pp. 124-143. 
Lo que nos estamos preguntando no es qué nos parece la tortura, pregunta a la que cualquier persona no trastornada por completo contestará que muy mal. Lo que se quiere analizar es si, en el plano de la pura teoría moral, el veto para la tortura tiene que ser total y absoluto, incondicionado, o si se admite que en alguna ocasión el torturar puede estar moralmente justificado (al margen de cuál sea la calificación jurídica de esa tortura) en razón del objetivo perseguido al torturar y por la gran relevancia de ese objetivo.

Para esa imprescindible delimitación de la materia de nuestro análisis ético, dos precisiones adicionales se imponen. En primer lugar, tenemos que subrayar que hablamos del razonamiento moral bajo condiciones teóricas apropiadas, lo que, ante todo, quiere decir en condiciones de imparcialidad. La teoría moral que se pretenda racional no se hace preguntándole a alguien qué haría cuando estuviera poseído por muy fuertes sentimientos o pasiones (aun cuando la ética actual trata de ser menos radicalmente impersonal y de tomar en cuenta también el papel de los sentimientos y afectos en el razonar moral), sino qué es racional o razonable hacer cuando se puede razonar libremente y desapasionadamente.

En segundo lugar, si lo que queremos es poner a prueba la afirmación de tantos autores de que moralmente la tortura es un mal absoluto y que en ningún caso puede estar, en la teoría, moralmente justificada, hemos de batirnos con distintos supuestos, hasta llegar a los que resultan más retadores para la teoría, entendiendo por tales aquellos para los que más fácil es imaginar justificaciones teóricas que puedan parecer racionales a sujetos no "degenerados". Veamos la siguiente escala de casos:

- (i) Un padre tortura al secuestrador de sus hijos para que le diga dónde los encerró. Vamos a prescindir en lo que sigue de este tipo de casos y a pensar nada más que en aquellos en que el torturador no obra "a título particular", por expresarlo así.

- (ii) Un agente del Estado tortura para obtener informaciones que le permitan organizar más efectivamente medidas de prevención de delitos o de aseguramiento de bienes o personas.

- (iii) Un agente del Estado tortura para lograr información que le permita detener o juzgar al autor de un delito, delito ya cometido y cuyos efectos ya no tienen vuelta atrás. El fin de esa tortura es nada más que el de aplicar castigo al culpable de ese delito.

- (iv) Un agente del Estado tortura para evitar un delito todavía no consumado y que pone en riesgo bienes importantes de personas. Aquí cabría diferenciar según cuántas sean esas personas amenazadas (no es lo mismo que se una o que sean 
diez mil), cuál es la gravedad o certeza de la amenaza y cuáles sean esos bienes bajo amenaza (no es igual que se trate de propiedades inmobiliarias o de la vida o la integridad física de personas, por ejemplo).

En adelante vamos tan solo a poner a prueba la justificación o no de la tortura en casos del tipo (iv) especialmente rotundos. Pensaremos únicamente en supuestos que reúnan las siguientes características:

a) Se tortura para evitar un mal, no para castigarlo o para que pueda ser castigado después de acontecido.

b) Ese mal lo es porque afecta de modo radical a la vida o la integridad física de una cantidad grande de personas, personas que, además, son totalmente inocentes.

c) La amenaza es plenamente cierta y tampoco cabe duda razonable sobre si el torturado es el responsable o corresponsable de esa amenaza y puede revelarnos cómo evitar su consumación ${ }^{13}$.

Sí, a la postre, estoy diciendo que pensemos en casos como los de la ticking-bomb o bomba de relojería ${ }^{14}$, pero con un aditamento: suprimiendo, experimentalmente o a modo de hipótesis de trabajo, todas las posibles dificultades epistémicas que fundan, con muchísima razón, gran parte de las críticas habituales a ese ejemplo ${ }^{15}$. 0 sea, que damos por sentado que la policía está absolutamente segura de que el detenido puso la bomba, que es objetivamente cierto que la puso y que va a matar a miles de ciudadanos si estalla, que no hay otra manera de evitarlo que no sea la confesión del terrorista, etc.

Conviene resaltar con fuerza que estamos tratando de movernos en el ámbito de la teoría moral o ética, no de los sentimientos morales o de las convicciones morales individuales sin más. A una persona le pueden preguntar si piensa que la conducta K es moralmente muy reprochable, gravemente inmoral, y puede contestar

13 Con estas dos condiciones unidas trato de diferenciar de supuestos de otra clase, como esta: un científico no tiene ninguna responsabilidad sobre la amenaza, pero es el único que, por sus conocimientos, sabe cómo desactivarla. Se niega a colaborar y se suscita el problema de su estaría o no justificado torturarlo para salvar tantas vidas.

14 Hay infinitas versiones de ese supuesto. Recojo aquí la versión estándar, tal como la resume MarionA Llobet Anglí "iEs posible torturar en legítima defensa de terceros?", InDret, 2010, p. 8: "un terrorista que acaba de ser capturado confiesa que ha puesto una bomba en algún lugar (o que conoce su ubicación), la cual estallará de modo inminente y matará a cientos, miles, 0, incluso, millones de personas. Por tanto, tal escenario tiene tres elementos: primero, la vida de muchos civiles inocentes está en peligro; segundo, la catástrofe es inminente; y, por último, un terrorista que ha sido capturado conoce información que podría evitar que dicho desastre ocurra".

15 Como señala Sussman, si lo que objetamos a la tortura es el riesgo de error, excluido por completo ese error en algún caso, decae también dicha objeción y se tendría que admitir la legitimidad de la tortura David Sussman, "What's Wrong with Torture?", Philosophy \& Public Affairs, 33, 2005, pp. 17-18. 
que sí. Si luego se le pregunta sobre las razones en que basa ese juicio moral suyo, hay la posibilidad de que responda que no sabe exactamente por qué o que no sabe explicarlo, pero que eso no quita para que su convicción sea completa y sin reservas; o que así juzga porque sigue los mandatos de la Ley de Dios o las órdenes de tal 0 cual libro sagrado y que, por tanto, es la fe lo que la guía; o que es lo mismo que opina sobre K el líder de la tribu o el jefe de su grupo político y que ella se lo cree a pies juntillas por razón de la inteligencia y perspicacia de aquel sujeto. Semejante convicción subjetiva puede ser muy profunda, radicalmente sentida por dicha persona, pero desde el punto de vista de la teoría moral al uso diríamos que no es muy racional. ¿Por qué? Porque no es capaz de dar razones que, en principio y como tales, sean aptas para ser admitidas y analizadas por cualquiera en un razonamiento que se quiera intersubjetivamente racional.

También quien se acoja a una ética puramente deontológica y se pretenda un sujeto moral racional está compelido a dar razones. El "es así porque sí" o "porque yo estoy muy convencido, y punto" no es razón, por mucho que uno se declare lo que se declare: adscrito a un ética deontológica, a un ética de principios, al objetivismo o el realismo ético, etc.; ni, incluso, aunque se proclame afín al imperativismo ético 0 al emotivismo ético.

En cierto sentido, el no utilitarista se halla en mayores dificultades. El utilitarista puede explicar que él siempre calcula y que se inclina por la menor suma de males. Por ejemplo, un razonamiento utilitarista simple dirá que es mejor que uno solo padezca grave tortura en vez de que cien o mil mueran o sufran graves heridas y secuelas. El otro, el que se oponga a esa conclusión, asume la difícil carga de argumentar por qué estima moralmente más defendible que el terrorista de nuestro ejemplo no sea torturado, en lugar de que por causa de su bomba y porque no se le torturó mueran o sean heridos todos esos ciudadanos. Y, repito, si buscamos razones consistentes no nos podemos conformar con el "porque es pecado torturar", "porque Dios nos prohíbe la tortura", "porque la tortura es un horrendo crimen contra la dignidad humana", o similares. ¿0 sí basta eso, quizá porque no cabe ir mucho más allá? A fin de cuentas, se trata de elegir entre la vida e integridad de inocentes y la integridad de un sujeto que, precisamente, desprecia esa integridad de los otros y verá consumado su maléfico propósito si no se le tortura a él lo si él no cede ante la tortura, lo cual implica que sacrifica su propia integridad para atentar contra la de aquellos otros inocentes). Se le estarían aplicando las reglas contra el juego sucio a quien, precisamente, juega más sucio ${ }^{16}$.

16 Cfr. Sussman, op. cit. p. 18. Este es un argumento decisivo para Henry Shue. En los supuestos que contemplamos y bajo esas condiciones estrictas, el torturado no se encuentra absolutamente 
En el deontologismo poco elaborado que niegue la justificación moral de la tortura en tales casos y bajo esas condiciones podría verse un cierto rastro del razonar sobre lo sagrado o sobre el pecado $0^{17}$ horrendo, indicio del pensar religioso ${ }^{18}$. Quizá no es malo que así sea. Pero es curioso que tal razonamiento recuerde al del fiel de determinada religión que prefiere la muerte segura de su hijo antes que permitir que se le trasfunda sangre y con ello se vulnere lo que interpreta como prohibición divina ${ }^{19}$.

El deontologista radical o absolutista moral corre el peligro de volverse tautológico. En nuestro caso, si con unas palabras u otras viene a decir nada más

indefenso o completamente a merced de ser torturado a capricho por el otro, ya que puede dar la información que tiene y que se le requiere para evitar el mal que de su propósito y voluntad depende. En cierto sentido, el torturado no está radicalmente inerme, sino que se está enfrentando al torturador para que se consumen sus fines malvados. Por ejemplo, para que no deje de ser gravemente torturado el inocente (ese sí, inocente) al que la policía trata de rescatar antes de que muera. Bastaría, pues, añadir un elemento más al modelo teórico o hipotético, el de la garantía de que la tortura vaya a acabarse en cuanto el torturado dé esa información que se le pide para salvar a los inocentes Cfr. H. SHuE, "Torture”, op. cit., p. 52-53.

17 En su crítica a la idea de prohibición moral absoluta y sin condición o justificación posible, McMahan (que sí es partidario de la prohibición jurídica completa) recuerda que tal carácter absoluto supone que, por ejemplo, una tortura consentida por la propia víctima (pone McMahan un buen ejemplo al respecto) seguirá siendo moralmente reprobable. Como, en palabras de dicho autor, "lo absoluto es absoluto: no hay excepciones para el consentimiento o las buenas intenciones", ocurriría lo mismo que la Iglesia Católica dispone para la prohibición absoluta del homicidio intencional de un inocente, que abarca también el suicidio y la eutanasia voluntaria del mismo modo que cualquier modo de homicidio" Jeff McMahan, "Torture and Method in Moral Philosophy", en Scott Anderson and Martha Nussbaum, eds., Torture, Law, and War, Chicago, University of Chicago Press, 2016. Cito por la versión digital descargable de la página del autor: http://jeffersonmcmahan.com/wp-content/ uploads/2012/11/Torture-and-Method-in-Moral-Philosophy.pdf

18 En 1958 explicaba Anscombe que para la tradición de la ética judeo-cristiana lo característico era que determinadas cosas estaban prohibidas fueran cuales fueran las consecuencias. Se trataba de cosas tales como matar a un inocente con algún fin, idolatría, sodomía, adulterio o jurar en vano. "The prohibition of certain things simply in virtue of their description as such-and-such identifiable kinds of action, regardless of any further consequences, is certainly not the whole of the HebrewChristian ethic; but it is a noteworthy feature of it" G.E.M. Anscombe, "Modern Moral Philosophy", Philosophy, 33, n 124, 1958, p. 8.

190 leamos esto: "Recogemos aquí el núcleo de la enseñanza tradicional de la Iglesia, reafirmada con frecuencia y con vigor durante el reciente Sínodo. En efecto, éste no sólo ha vuelto a afirmar cuanto fue proclamado por el Concilio de Trento sobre la existencia y la naturaleza de los pecados mortales y veniales, sino que ha querido recordar que es pecado mortal lo que tiene como objeto una materia grave y que, además, es cometido con pleno conocimiento y deliberado consentimiento. Es un deber añadir — como se ha hecho también en el Sínodo- que algunos pecados, por razón de su materia, son intrínsecamente graves y mortales. Es decir, existen actos que, por sí y en sí mismos, independientemente de las circunstancias, son siempre gravemente ilícitos por razón de su objeto. Estos actos, si se realizan con el suficiente conocimiento y libertad, son siempre culpa grave" (Exortación Apostólica Post-Sinodal Reconciliatio et Paenitentia, de Juan Pablo II, 1984, apartado 17). 
que la tortura es moralmente horrible porque es moralmente horrible y por eso nunca, en ningún caso y bajo ninguna condición, puede estar moralmente justificado torturar, nos deja nada más que una curiosa sensación a los que dudamos sobre la cuestión de la tortura y no somos absolutistas morales: la sensación de que el absolutista es alguien que está muy convencido de que algo es malo aunque no sepa explicar por qué (salvo cuando usa un argumento de autoridad y se remite al mandato de algún dios).

Jeremy Waldron, por ejemplo, se proclama un absolutista moral en su rechazo de la tortura e insiste en que bajo ninguna condición y ni con la más extrema reelaboración de ningún ejemplo de la bomba de relojería o similar se podrá considerar moralmente admisible la tortura ni en un solo caso. Cuando Susan Mendus le dijo que no daba razones de su postura y que esa radical actitud nada más que se podía explicar por su bien conocida y reconocida fe cristiana ${ }^{20}$, Waldron se molestó bastante y escribió un artículo titulado "What are moral absolutes like?"21. Repasa diferentes argumentos que el absolutista como él podría oponer al consecuencialista que presenta supuestos cada vez más trágicos del caso de la bomba de relojería, para que este no diga que el absolutista se cierra en banda y nada más que repite que lo que no puede ser no puede ser, y concluye Waldron que en verdad ninguno de esos argumentos funciona demasiado bien. Esa conclusión suya es devastadora para su absolutismo, como él mismo viene a reconocer, pero no por eso renuncia al mismo ni lo pone en cuestión. Estas son las últimas palabras de su artículo: "Since no conclusive answer has been furnished to our question -How are moral absolutes supposed to work?- it is tempting to say pessimistically that the absolutist must admit defeat. This is inferring too much, I think, except in the ordinary sense that the absolutist concedes right here and now that he has not done what he would like have done. But nothing has been done to show that the question we have posed for the absolutist cannot be answered. And, if I say so myself, a certain amount of progress has been made indicating, first, what such an answer cannot be like, and secondly what it may be like. Both kinds of progress are important -the first, for indicating threads worthy of further exploration, and the second for redeeming us from wasteful excursions that do not really address the heart of the problem"22.

Pocas veces leeremos una tan honesta confesión de fracaso al intentar justificar argumentalmente una postura filosófico-moral. A fin de cuentas nos está contando Waldron que él no se apea de decir que moralmente es condenable la tortura incluso

20 Susan Mendus, "Professor Waldron Goes to Washington", Criminal Law \& Philosophy, 8, 2014, p. 125.

21 Harvard Review of Philosophy, 18, 2012, pp. 4-30

22 Ibid., p. 30. 
en el caso de que sea el torturar a uno solo la única manera de evitar que se acabe el mundo y mueran todos, incluido aquel candidato a la tortura.

Mendus y Waldron debaten desde ubicaciones distintas. Waldron insiste en que él habla antes que nada sobre el significado jurídico de la tortura y que la prohibición jurídica que para la tortura rige es absoluta. Pero no puede negarse que apoya esa tesis en una forma de absolutismo moral. Además, en opinión de Waldron, legitimar jurídicamente la tortura en algún caso extremo sería caer en una pendiente resbaladiza con dos graves riesgos simultáneos, ya que tanto supondría el peligro de que se fuera abriendo la mano a cada vez más casos de tortura a partir de aquellos primeros casos extremos (el de la bomba de relojería, por ejemplo), como el de que progresivamente nos fuéramos habituando de manera acrítica a que los estados vulneren hasta las más valiosas prohibiciones jurídicas y se degrade gravísimamente el Estado de Derecho, con pérdida para todos los ciudadanos. Por su lado, y como resalta el propio Waldron en su respuesta ulterior, no parece que a Mendus le interese gran cosa el aspecto jurídico, sino que le importa el problema moral, tanto el de si pueden existir absolutos morales, como el de si es un tal absoluto el que toca la prohibición de torturar. Mendus afirma que puede haber casos en que quepa ver como moralmente lícita la tortura, y muy en especial casos en que pueda tenerse como moralmente admisible que un político, en ejercicio de su responsabilidad, mande torturar. Lo que no quita para que Mendus expresamente subraye que le parece bien que se conserve la prohibición jurídica de torturar, genéricamente y sin acoger excepción de modo expreso. Waldron, insistiendo en que él ha hablado de derecho más que de teoría moral, termina su respuesta a Mendus indicando que cree que sí existen absolutos morales, “ciertas cosas que están absolutamente prohibidas por la moral.... si no la tortura, pues entonces la violación; si no la violación como tal, entonces la violación de un niño pequeño si ese es el único modo de persuadir a sus padres para que revelen dónde han escondido una bomba de relojería"23.

\section{Humanidad e inhumanidad}

Quizá el argumento más usado para justificar el carácter absoluto de la prohibición moral de torturar (una vez que se asuman las condiciones epistémicas con las que, a título de hipótesis, estamos trabajando) es el de que la tortura es posiblemente la más grave y peculiar violación de lo que de humanidad hay en el

23 Jeremy Waldron, "Responses to Zedner, Haque and Mendus", Criminal Law \& Philosophy, 8, 2014, p. 145. El objeto inicial de la crítica de Susan Mendus había sido el libro de J. Waldron titulado Torture, Terror and Trade-Off. Philosophy for the White House, Oxford, Oxford University Press, 2010. 
sujeto, su anulación como persona. Es un argumento potente y que viene reforzado con todo tipo de estudios sobre las secuelas psíquicas y vitales en los torturados. La víctima de la tortura no es meramente tratada como un objeto 0 instrumento al servicio de fines ajenos, sino que es, en cierta forma, destruida. Y esa destrucción es más radical que cuando se mata a alguien, pues, al fin y al cabo, sí que suele haber acuerdo en que a veces puede estar moralmente justificado matar, como cuando se hace en legítima defensa. Como sostiene Sussman, nada degrada más la dignidad humana, nada la rebaja o la humilla tanto, incluso nada la merma tanto a los ojos del propio individuo que es torturado.

Me parece que esa muy respetable línea argumental puede ser puesta a prueba o cuestionada. Lo intentaré con unos pocos argumentos:

a) Creo que los móviles del torturado (y no solamente los del torturador) deben ser también tenidos en cuenta en nuestras disquisiciones morales. Comparemos las dos situaciones que siguen.

(i) Una banda de criminales persigue al hijo de X para matarlo con gran crueldad por una pequeña deuda de juego o por una leve ofensa del hijo de $X$ al hijo del jefe de esa banda. $X$ sabe dónde se esconde su hijo y los malos no dan con él. Pero se llevan a X y lo torturan para que diga dónde está el escondite.

(ii) La policía detiene a Z, que ha puesto la famosa bomba de relojería en algún lugar muy concurrido de la gran ciudad. La policía sabe con certeza (insisto en las condiciones epistémicas de la hipótesis con que trabajamos) que la bomba estallará en dos horas si antes no es desactivada. Entonces, la policía tortura a Z para que diga a tiempo dónde se halla la bomba.

¿Podemos entender que la degradación de la dignidad de X y de Z es la misma? $X$ resiste ante torturadores de la peor calaña y ese comportamiento de $X$ cualquiera lo tildará de heroico y extraordinariamente digno. Posiblemente él, en el fondo, se sentirá así también, en especial si con su resistencia consiguió salvar a su hijo. Por el contrario, $Z$ es un sujeto que quiere matar a inocentes, aunque lo haga movido por algún ideal subjetivo (vengar ofensas de su grupo, conseguir la independencia para su nación, exterminar infieles...) y quienes lo torturan pretenden la salvación de esos inocentes. ¿Quedan esas diferencias completamente eclipsadas u oscurecidas por el hecho de que el acto en sí de la tortura niega la humanidad o lo más esencial de la integridad de $X$ y de $Z$ ?

b) El argumento que voy a emplear ahora es delicado y pido que se considere en sus justos términos y como parte de lo que, a la postre, no es más que un intento de poner a prueba la resistencia e integridad de las convicciones morales sobre la tortura. La tortura degrada por el padecimiento físico y psíquico que acarrea, por 
el dolor y por la radical indefensión y humillación que el torturado experimenta. El torturador al que aquí nos estamos refiriendo no es el sádico gratuito, sino el que tortura para conseguir del otro alguna clase de información con el objetivo de evitar un grave mal para otros ${ }^{24}$. Pensemos en el caso en que la tortura se va aumentando a medida que el torturado resiste y no da la información que el torturador de él pretende. Aquellos padecimientos, por tanto, van creciendo durante el transcurso de la tortura; se va incrementando también el atentado contra la esencia de la dignidad o humanidad del torturado.

Ahora usemos de nuevo los ejemplos de hace un momento, los casos de $\mathrm{X}$ y de Z. Aventuro, como hipótesis para el debate, que cuanto más se tortura a $X$ hay un sentido (solo uno, pero uno sí) en que su dignidad crece cuanto más sufre, cuanto más aguanta para salvar la vida de su hijo. Y, por el contrario, cuanto más resiste Z para que sus innobles fines se consumen, tanto más demuestra que, en aquel mismo sentido, estaba ya de él ausente un componente básico de humanidad o dignidad. Porque, si no lo vemos así, deberemos admitir que es idéntico a todos los efectos y en toda su extensión el valor moral o dignidad de quien se sacrifica por un fin que cualquier sujeto razonable no puede dejar de considerar elevado y moralmente loable, y el valor moral o dignidad de quien está dispuesto a asumir hasta los más atroces padecimientos para cobrarse la vida de infieles inocentes o de ciudadanos sin culpa un régimen político que detesta. Mientras que $X$, en cierto sentido, se humaniza a medida que aguanta la inhumana tortura, $Z$ se degrada también por sí mismo durante ese proceso. Lo que intento apuntar es que la inhumanidad o indignidad de la tortura no puede, en nuestros razonamientos morales, ser completamente ajena a las diferencias en humanidad o dignidad de los propios torturados (y de los mismos torturadores). Pues, en caso contrario, habríamos de calificar moralmente de forma perfectamente idéntica y negativa en el mismo grado la tortura que un Hitler inflige a un judío para que le diga dónde se esconden sus niños, a fin de llevarlos a la cámara de gas, que la que un judío inflige a un Hitler para que le diga dónde está la cámara de gas, a fin de poder volarla y salvar a sus niños y a otros niños judíos.

\section{4. ¿Y la legítima defensa?}

Como tantos autores han apuntado, no es sencillo explicar por qué cabe matar en legítima defensa y no cabe torturar en legítima defensa, usando esta expresión

24 Repito que estoy excluyendo de este razonamiento no solo los casos en los que el torturador no busca más que su propio placer enfermizo, sino también aquellos en los que se pretende conseguir con la tortura que el torturado confiese que él cometió un delito cuyos efectos ya no tienen remedio posible. 
ahora en sentido moral y no técnico-jurídico o jurídico-penal. La muerte elimina también la humanidad de la víctima. 0 pensémoslo de otra manera. Imaginemos durante un rato un ejemplo así: la policía sabe con plena certeza y seguridad (de nuevo las condiciones epistémicas especiales) que varias personas inocentes están siendo gravísimamente torturadas en un escondite de una banda de sádicos. Detiene la policía a uno de los de esa banda que conoce dónde están ocurriendo esas torturas y se niega a declarar. Si, en aras de salvaguardar su dignidad, no se le tortura, seguirá padeciendo la dignidad de los otros inocentes que están siendo torturados. ¿No habría tampoco legitimidad moral ninguna de la tortura por la policía en ese caso?

Supongamos el ejemplo siguiente, que es de mi cosecha y que tiene dos partes.

Parte primera. P es una persona inocente que ha sido secuestrada por dos asesinos, $W$ y $Z$, que la quieren matar. Han decidido matarla hoy a las cuatro de la tarde en el escondite secreto al que la llevaron y donde W la custodia y la va a ejecutar a esa hora. W tiene una grave enfermedad cardiaca y lleva implantado una especie de marcapasos. Si el marcapasos se detiene, W muere en el acto. Ese peculiar marcapasos puede manejarse a distancia con un aparato que está en poder de la policía. A las 15:59, cuando la policía sabe (asúmase otra vez la peculiar condición epistémica del ejemplo) que W ya se dispone a ejecutar de un tiro en la cabeza a P y está tomando la pistola para ello, la policía mata a W pulsando la tecla del aparato que hace que el corazón de $W$ se detenga. La policía no tenía otro medio de llegar a W, pues ignoraba por completo dónde estaba el refugio. Si nos preguntamos si fue moralmente legítima (y, además, jurídicamente legítima) la acción de la policía al matar a W, diremos que sí, que se trata de un genuino y justificado acto de legítima defensa de tercero y, además, la policía está cumpliendo con su deber, de modo bien similar a cuando, no cabiendo otra alternativa menos dañina, dispara y mata al que está a punto de ejecutar a un ciudadano inocente.

Segunda parte del ejemplo. Una hora más tarde, la policía logra detener a Z. La policía sabe que por las peculiaridades de la situación de P y del escondite en el que Z y W lo encerraron, P morirá en veinticuatro horas por falta de oxígeno, si no llega antes la policía a rescatarlo. Así que interrogan a Z y este reconoce toda su responsabilidad, pero se niega tajantemente a informar de dónde está ese escondite y hasta dice que es porque quiere que $P$ muera, y muera con fuerte sufrimiento. Van veintidós horas así. La policía sabe que P está encerrado en algún sitio en un radio de cien kilómetros. Apenas queda ya tiempo para salvarlo, si la información llega. Pero $Z$ sigue en sus trece. Entonces la policía le aplica tortura a Z, muy dolorosa pero que 
no le dejará secuelas físicas perdurables. A los quince minutos, $Z$ dice dónde se halla el escondite. La policía rescata vivo a P.

Esos policías han hecho dos cosas en dos momentos distintos, ambas con el fin de salvar la vida a $\mathrm{P}$, y las dos alcanzaron ese objetivo. Una fue matar a W; la otra, torturar a Z. La inmensa mayoría, de los ciudadanos o tratadistas dirán que estuvo moralmente justificado el matar a W. Muchos, tal vez la mayoría de los que sobre los problemas morales de la tortura escriben, afirmarán que fue moralmente ilícita la tortura de Z, pues la prohibición moral de torturar es absoluta y no admite excepciones en ningún caso, a diferencia de la prohibición moral de matar, que sí permite excepciones, como la de legítima defensa.

Como ya he señalado, el argumento más utilizado a favor del carácter absoluto de la prohibición moral de torturar es el que señala que la tortura constituye un atentado tan radical y esencial contra la dignidad del ser humano, de la víctima de la tortura, que supone nada menos que la negación rotunda de su humanidad, lo peor (o una de las dos o tres cosas peores) que a una persona se le puede hacer, lo más perverso y salvaje, la suprema negación de la naturaleza humana de la víctima (y, se dice también a menudo, del torturador). Un ser humano así privado de su dignidad es un ser humano al que se ha robado su humanidad, el núcleo mismo de su cualidad de persona. Sin embargo, poquísimos serán, de los autores que así respaldan lo absoluto de la interdicción moral de la tortura, los que digan que nunca puede estar moralmente justificado matar en legítima defensa, sea propia o de tercero. 0 sea, que, en nuestro ejemplo, habría justificación para que la policía quitara la vida a W, pero no para que torturara (quitara la dignidad) a Z. De lo que se desprenden dos consecuencias inquietantes 0 un tanto desconcertantes: a) que la dignidad de $Z$ (el secuestrador de P y que quiere que P muera, aunque sea al precio de ser él mismo, $Z$, torturado) tiene mayor valor o relevancia moral que la vida ${ }^{25} \mathrm{de} \mathrm{W}$, pues la moral

25 Esta paradoja la expresa con maestría Llobet Anglí: "hay autores que aluden a la dignidad humana (que resulta atacada por la tortura) como bien de tal calibre cuyo ataque no es posible de justificar bajo ninguna circunstancia. Sin embargo, tal solución plantea, a mi modo de ver, dos problemas. Por un lado, no se aporta ningún argumento lo suficientemente sólido e incontrovertido que demuestre que la dignidad o la integridad moral de una persona es un bien de mayor relevancia que su vida. Por tanto, si matar puede estar justificado mediante la legítima defensa, también puede estarlo torturar" ("iEs posible torturar en legítima defensa de terceros?", cit., pp. 26-27). Y suma este argumento adicional, nada desdeñable si queremos algo de congruencia doctrinal: "Por el otro lado, si la prohibición absoluta de esta práctica se fundamenta en el mero atentado contra la dignidad de las personas, la tortura cometida por particular también debería ser típica, puesto que la conducta en sí es idéntica y vulnera el mismo bien jurídico. Sin embargo, la tortura sólo se castiga como forma de violencia patrocinada por el Estado, esto es, cuando el sujeto activo es un funcionario público" (ibid., p. 27). 
nos permite matar a W, pero no torturar a Z; b) que la dignidad de Z tiene mayor valor moral que la vida de $P$, pues la moral nos veta la tortura de $Z$ aunque sea la única vía posible para salvar a $\mathrm{P}$ y aun cuando $\mathrm{P}$ sea inocente y $Z$ sea el que soporta la tortura con tal de consumar su finalidad de que muera $P$ cruelmente.

Vista la cuestión desde otro lado, según aquella teoría del absoluto moral de interdicción de la tortura, podemos afirmar que la dignidad de una persona vale más que su vida misma y que, en consecuencia, es moralmente preferible dignidad sin vida, que vida habiendo sido torturado, pues es vida con la dignidad perdida 0 dañada sin remisión. En otras palabras, moralmente fue mejor lo que se le hizo a W (matarlo) que lo que se le hizo a Z cuando se lo torturó. Si, a tenor de la ética racional a la que cualquier sujeto debe aspirar, moralmente es preferible matar que torturar, porque el daño que se le hace a la víctima es mayor en la tortura que en la muerte, debido a que el bien suprimido por la tortura (la dignidad) pesa más que el bien suprimido al dar muerte (la vida), entonces cualquier sujeto moral racional debería moralmente preferir: a) matar antes que torturar, cuando son las únicas alternativas para salvar la vida de alguien; b) ser matado antes que ser torturado, porque el que pierde la dignidad pierde algo de valor moral más alto que la vida misma.

De esa categoría son las incoherencias que subraya McMahan, profesor de filosofía moral en la Universidad de Oxford, aunque manejando otros ejemplos. Dice que, admitido que tanto el matar como el torturar pueden ser "defensivos" y que "es menos malo ser torturado que ser matado, resulta implausible pretender que una persona puede, por razón de su responsabilidad, ser matada con un fin puramente defensivo, pero no puede ser torturada por un fin puramente defensivo"26.

Los matices que introduce McMahan son esenciales y los comparto. Sus ejemplos (o el mío de hace un momento, me permito decir) o el ejemplo típico de

26 Jeff McMahan, "Torture and Method in Moral Philosophy", cit. Añade, por ejemplo, esto: "Es incuestionable que para una persona que podría por lo demás tener una vida larga y feliz más adelante, sería peor ser matado que padecer tal sufrimiento durante una hora, especialmente si la tortura no le causa daños físicos permanentes".

Similarmente, Frances M. Kamm, que presenta el caso en que el plan de un sujeto que ha dispuesto intencionadamente la muerte de inocentes solamente puede ser abortado o bien matando a ese sujeto, o bien torturándolo durante una hora. Según Kamm, si, para la salvación de esos inocentes y siendo ese sujeto moralmente responsable del riesgo de muerte bajo el que se hallan, la única alternativa a matarlo es torturarlo, es moralmente admisible torturarlo; y, puesto que matarlo estaría moral y jurídicamente admitido, el torturarlo, mal menor, iría en interés del propio torturado F.M. Kamm, Ethics for Enemies. Terror, Torture and War, cit. p. 15. Esa idea está presente también de modo muy significativo en Steven Greer, "Is the Prohibition against Torture, Cruel, Inhuman and Degrading Treatment Really 'Absolute' in International Human Rights Law?", Human Rights Law Review, 15, 2015, p. 104. 
la bomba de relojería son "hipotéticos" y "en particular nos ayudan a captar que no es plausible ver la tortura como moralmente prohibida de un modo absoluto". "Pero no se sigue de eso que deba estar permitida "as a matter of policy", "ni que debiera estar legalmente permitida" en algún caso. Si de las hipótesis de escuela pasamos a los hechos históricos, lo que vemos es que casi siempre la tortura ha sido usada de un modo inmoral, contra inocentes y para fines injustos, y por eso dice que él mismo ha argumentado en otros trabajos ${ }^{27}$ que "la tortura debe estar absolutamente prohibida por el derecho", pues es mucho más importante impedir la tortura de un inocente que brindar el poder legal de usar la tortura en los muy raros casos en los que pueda estar moralmente justificada"28.

\section{Conclusión provisional y aviso definitivo}

Me interesaba tratar sin prejuicios ni tabúes un asunto muy interesante de filosofía moral y política, el de si en algún caso puede considerarse moralmente justificada la tortura. Me he acercado mucho a la respuesta positiva a esa pregunta y quizá de esa manera provoco las iras de más de un bienintencionado dogmático. No por darles gusto, ni mucho menos para dar la razón a quien prefiere la censura a las razones, he de precisar mi planteamiento y debo repetir algún matiz.

Si apunto que posiblemente en algún caso sea racional o razonable considerar justificada la tortura, es sobre la base de los supuestos que he manejado y bajo las condiciones con que los he diseñado. La tesis no rige si los supuestos son otros o las condiciones son distintas. He querido decir que en algunas hipótesis bien precisas cabría ver moralmente justificada la tortura, pero que así sea en esas hipótesis

27 Cita su artículo "Torture in Principle and in Practice".

28 Merece lectura atenta también la siguiente consideración de McMahan, extraordinariamente útil, en mi opinión: "The motivation of those philosophers who have exercised their ingenuity in producing objections to the ticking bomb case is understandable and admirable: they want to deny any support to those who defend the practice of torture as a matter of law or policy. In this they are right; it is the duty of every decent person to oppose the legalization or institutionalization of torture. But that is not because torture is absolutely morally wrong. It is instead for the reason I gave: that it is morally far more important to prevent the torture of the innocent than it is to accord a legal privilege for torture in those exceedingly rare cases in which it would be morally permissible. Even as a tactical matter it seems wiser to base one's opposition to the practice of torture on such grounds as this than to persist in claiming that morality rules out torture absolutely. For the continued assertion of that claim is likely to do little more than to persuade the defenders of torture that their opponents are obtuse or naïve. The ticking bomb case is, after all, highly effective in convincing people that torture is not absolutely wrong. Tactically, then, it is better simply to grant that and to focus one's efforts instead on explaining why the fact that torture can be morally permissible in certain rare circumstances is largely irrelevant to matters of law or policy in a world in which vicious rulers clutch at every possible rationale for the use of torture in the service of unjust ends". 
no conlleva, en modo alguno, que lo mismo valga para otras hipótesis o casos distintos ${ }^{29}$. Es exactamente igual que si razonamos que matar en legítima defensa puede tener justificación moral bajo tales y cuales condiciones y de ahí se saca que estamos diciendo que está moralmente justificado matar también si no se presentan dichas condiciones. El non sequitur es patente. Yo he escrito lo que he escrito, y no comulgo, en este tema, más que con lo que he escrito. Y estoy convencido, de propina, de que, puestos a luchar eficazmente contra el horror de la tortura, lo haremos mejor a base de reflexión libre y matices complejos que desde el espíritu cuasi religioso de tanto catequista laico de nuestra época.

Cuanto he indicado o aventurado es por completo compatible con mi absoluto rechazo a cosas tales como las torturas aplicadas por el ejército o los cuerpos de seguridad de EEUU en las cárceles de Abu Ghraib, mismamente ${ }^{30}$. Las condiciones que he puesto a los casos con los que he razonado son tan excepcionales (empezando por las que he llamado condiciones epistémicas), que seguramente no se darán nunca, o casi nunca ${ }^{31}$. Lo que he querido cuestionar o poner a prueba es nada más

29 Escribe Luis Greco lo que sigue: "en una argumentación jurídica y moral no existen puntos de vista que sólo valgan de manera excepcional. Todo punto de vista relevante, es decir, todo punto de vista al que ante algún problema se le atribuye una relevancia moral o jurídica conserva también esta relevancia frente a todo problema equivalente. Con otras palabras: en el mundo de la argumentación jurídica y moral no existen excepciones, entendidas éstas como puntos de vistas relevantes que solamente son relevantes en un sector 0 ad hoc. Cada excepción es la expresión de una regla que le sirve de base, que regula, justamente, cómo debe decidirse en el caso de situaciones excepcionales (“Las reglas detrás de la excepción. Reflexiones respecto de la tortura en los grupos de casos de las ticking time bombs", In Dret, abril de 2007, p. 20). Puede que haya aquí un poco de confusión lógica o metodológica. Cuando proponemos el trato normativo T para el caso C, estamos proponiendo ese trato para $\mathrm{C}$ y todos los demás casos a él iguales en cuanto se establezca como normativamente relevante, en lo determinado como relevante a efectos de definición de C para T. Por ejemplo, yo digo que las circunstancias epistémicas del caso de la bomba de relojería son absolutamente decisivas, de modo que cuando no se dan (sea en un ejemplo ficticio, sea en un caso real), no se cumplen los presupuestos para aplicar el tratamiento normativo propuesto, que aquí sería el de permisión (no prohibición) moral de la tortura. Es como si alguien defiende que está moralmente permitido el aborto voluntario en el caso en que el embarazo es causado por la violación de la mujer. De ahí nada se sigue normativamente para casos diferentes (por ejemplo, embarazo causado por error de la mujer sobre la identidad del varón que provoca el embarazo). Toda regla rige para su supuesto, no para otros supuestos.

30 En la penalística española, Llobet Anglí, que admite que en casos como el de la bomba de relojería puede aplicarse la eximente de legítima defensa en favor de terceros al autor de la tortura (siempre que concurran los requisitos de la legítima defensa, claro), puntualiza de modo rotundo que esa opinión suya para nada equivale ni a ser partidario de la legalización de ninguna tortura ni a simpatizar con asquerosas prácticas como los cometidas en Guantánamo o Abu Ghraib M. Llobet Anglí, "iEs posible torturar en legítima defensa de terceros?", cit., pp. 33 y 37.

31 "Disparing remarks about torture in Argentina and Abu Ghraib are also common, yet these are about as far from ticking-bomb cases as one could get and still be talking about torture" F. AццноF, Terrorism, 
que la presentación de la prohibición moral de torturar como un absoluto moral sin excepción posible, o como una prohibición que bajo ningún concepto decae en cualquier mundo posible o en cualquier tesitura real o imaginaria de nuestro mundo. Además, me declaro ferviente partidario de que la prohibición jurídica de la tortura siga siendo total y plena ${ }^{32}$. Abrir la espita de los permisos para casos excepcionales acarrea el peligro cierto de que empiece la pendiente resbaladiza ${ }^{33}$, de que vaya aumentando el "agujero" o de que acabe convirtiéndose en regla la excepción, sin dejar de disfrazarse de excepción mientras ya es regla ${ }^{34}$. Es lo que Fernando Molina llama el argumento de la "ticking-bomb como caballo de Troya"35.

Ticking Time-Bombs and Torture. A Philosophical Analysis, Chicago, The University of Chicago Press, 2012, pp. 134-135.

32 Luis Greco defiende el carácter absoluto de la prohibición jurídica de la tortura y apunta que esa defensa se pone a prueba ante casos extremos como los llamados de la bomba de relojería (Luis Greco, op. cit.). McMahan pone en solfa el carácter absoluto de la prohibición moral de torturar, pero defiende que la prohibición jurídica sea total y no tenga excepciones. Lo justifica con el argumento de que hay que negar a los torturadores todo pretexto posible para torturar, ya que en la inmensa mayoría de los casos el torturar será moralmente malo. Dice que es lo mismo que pasa con otras cosas que pueden en alguna oportunidad puntual estar moralmente justificadas, pero que es mucho mejor que en ningún caso estén jurídicamente permitidas, a fin de evitar el posible abuso. Así sucedería, por ejemplo, con la muerte intencionada de civiles en la guerra o con la guerra preventiva J. McMahan, "Torture and Method in Moral Philosophy", cit.

33 "Es dudoso que la tortura pueda ser restringida a situaciones extremas y que no se convierta en rutina" Claudia Card, "Thickinig Bombs and Interrogations", Criminal Law and Philosophy, 2008, p. 4.

34 0, como dicen muchos autores también, se trata del "peligro de la ruptura del dique". En palabras de Luis Greco, "La admisión de la tortura, también para una situación excepcional, significa la rehabilitación de una estrategia de superación de un problema que sería mejor que continuara desterrada del ámbito de lo que debe ser considerado" (Luis Greco, op. cit., p. 18). Greco está discutiendo con quienes pretenden que se flexibilice la prohibición jurídica de la tortura, en particular con los penalistas y constitucionalistas alemanes que así han argumentado. En ese ámbito, estoy de acuerdo con él. Pero cierto es que, por su modo de razonar, parece que Greco se mueve simultáneamente en el terreno de la teoría moral y el de la teoría jurídica. Frente a eso, digo dos cosas. Una, que parece coherente que los autores que demandan la autorización jurídica de la tortura en determinados casos consideren que en esos mismos casos hay también una justificación moral de la tortura, pero que la inversa no se sigue. Quiero decir que no siempre que en algún caso pueda considerarse moralmente justificada la tortura hay por qué automáticamente entender que también debe, para esos casos, permitirse jurídicamente. Lo otro que digo es que intuyo que no tiene mucho sentido aplicar el argumento de la pendiente resbaladiza o de la ruptura del dique en el ámbito de la teoría moral. En teoría moral cabe perfectísimamente que defendamos reglas absolutas (como la de la que moralmente prohíbe la tortura sin excepción posible, según muchos autores), pero no que metodológicamente nos prohibamos atenuar para algún caso alguna prohibición moral por temor a que, entonces, acabemos relativizando muchas más reglas morales. Creo que eso iría contra la racionalidad intrínseca del razonamiento teórico-moral.

35 "Cuesta mucho erigir un sistema jurídico que sirva de verdadero freno contra los abusos del poder. El argumento de la ticking bomb opera como un caballo de Troya. Le abrimos las puertas y finalmente la fortaleza de los derechos humanos es tomada. Hemos, como mucho, salvado una situación concreta 
Por una parte, de que la conducta $\mathrm{X}$ pueda estar moralmente justificada en algún caso no se desprende que tenga que estar jurídicamente justificada en ese mismo caso. Hay conductas moralmente admisibles para cuya prohibición jurídica concurren razones muy fuertes. Por otra parte, o viendo lo anterior desde otra perspectiva, "a veces puede estar moralmente permitido incumplir el derecho"36.

Tampoco soy nada partidario de que jurídicamente la cuestión se resuelva a base de ponderar, pues ese camino conduce a lo mismo, a que sean los poderes establecidos (entre ellos, el poder judicial) los que caso a caso determinen si la tortura es jurídica y constitucionalmente lícita o no. Jurídicamente no puede ni debe caber más que el veto.

Pero tampoco somos tan ingenuos como para desconocer la milenaria inteligencia y los recovecos de lo jurídico. En esos casos con los que hemos estado trabajando para nuestra reflexión sobre el problema moral de la tortura, nuestros sistemas jurídicos no aliviarían la prohibición de torturar ni el calificativo de antijurídicas para las torturas. Pero seguramente en ellos hallaríamos eximentes para los torturadores, para los torturadores de esos casos, no de cualesquiera otros. Eximentes como la legítima defensa o el estado de necesidad, mismamente. La vieja y muy reposada sabiduría de los juristas tiene mucho que enseñar a los teóricos de la ética. Más, incluso, que a la inversa. Por eso hace tanta falta también que los filósofos del derecho sepamos bastante derecho. Haré un breve excurso sobre el tratamiento que la doctrina penalista da al tema de la tortura.

\section{Sobre las posibles consecuencias penales para el tortu- rador cuando la tortura puede estar moralmente justificada}

Posiblemente el penalista más respetado de las últimas décadas en el ámbito del llamado derecho continental es Claus Roxin ${ }^{37}$. Refiriéndose no primeramente a

a cambio de condenar a un número incontable de otras" Fernando Molina Fernández, "La ponderación de intereses en situaciones de necesidad extrema: ies justificable la tortura?", en A. Cuerda Riezu -dir.-, La respuesta del Derecho penal ante los nuevos retos, Madrid, Dykinson, 2006, p. 280.

36 F.M. Kamm, Ethics for Enemies. Terror, Torture and War, cit., p. 53.

37 Christian Jäger enumera las cuatro posiciones de la dogmática penal alemana reciente sobre la cuestión del tratamiento penal de la tortura en casos extremos: negación categórica de cualquier posible justificación jurídica en cualquier caso; justificación cuando se trate de salvar inocentes, sobre la base de ponderar la dignidad del autor de la agresión contra la dignidad de las víctimas; justificación posible para la amenaza de tortura, pero no para la tortura misma; y posible concurrencia, en casos extremos, de una causa de justificación supralegal. Esta última sería la tesis de Roxin. Vid. CHR. JäGer, "Das Verbot der Folter als Ausdruck der Würde des Staates", en Strafrecht zwischen System und Telos. Festschrift für Rolf Dietrich Herzberg zum siebzigsten Geburtstag, Tübingen, Mohr Siebeck, 2008, p. 540. 
hipótesis teóricas de escuela como la de la bomba de relojería o del tipo de las que aquí he venido manejando, sino a supuestos como el del caso Daschner, juzgado en Frankfurt en 2004, escribe Roxin que la prohibición en el derecho alemán es incuestionable, y también lo es esa amenaza de tortura a un secuestrador para salvar de la muerte a su víctima inocente, a lo que se suma que la conducta del acusado, un jefe superior de policía, era culpable, pues "conocía la regulación al respecto y podía haber actuado de otro modo, tal y como su asesor le había recomendado"38. Mas a continuación escribe esto: "Pero, iexiste realmente una necesidad preventiva de sanción? Si se toma en consideración que el autor quería salvar una vida humana y que actuó de acuerdo con su conciencia y no por estímulos criminales, cabe la posibilidad de tomar en consideración una causa de exclusión de la responsabilidad supralegal, puesto que en este tipo de supuestos trágicos no se debe reaccionar necesariamente con una pena ${ }^{39}$. El Tribunal que conoció del caso no reparó en una solución como la propuesta, sin embargo llegó a una solución parecida a través del recurso a una mera «amonestación» (§ 59 StGB), esto es, a través de la sanción más leve que el Derecho penal alemán conoce, de contenido más bien simbólico"40

Ciertamente, no está Roxin tratando de la calificación moral, sino jurídicopenal, de la acción de aquel torturador. Pero, admitido que el acusado operó con plena conciencia y sin error que lo excuse, parece que la propuesta de que se le aplique "una causa de exclusión de la responsabilidad supralegal por ausencia de necesidades preventivas" se puede relacionar con que su conducta seguramente no

38 Claus Roxin, "El nuevo desarrollo de la dogmática jurídico-penal en Alemania", InDret, octubre de 2012, p. 11.

39 Se acostumbra a decir que con el planteamiento de Roxin, una causa supralegal de exclusión de la responsabilidad concurre cuando no tienen sentido ver un comportamiento como penalmente exigible. Se suele explicar que es la no exigibilidad de la conducta típica lo que exculpa. Esa no exigibilidad es lo que concurre como fundamento de las causas de justificación tales como la legítima defensa o el estado de necesidad, pero también aparece como causa genérica de carácter supralegal. Pero como ha venido explicando el mismo Roxin, los casos en que esa causa de exclusión puede concurrir "no se pueden solventar sencillamente con la causa de exclusión que es la «inexigibilidad». Se trata solamente de determinar si de los principios político-criminales (basados por su parte en la ley), rectores de la categoría de la responsabilidad, es lícito deducir la exclusión de la penalidad respecto de determinados tipos de situaciones claramente perfilados, aunque el legislador no contemple tales constelaciones (y, por tanto, tampoco se haya pronunciado implícitamente en contra de que se las tome en consideración)" Claus Roxin, Culpabilidad y prevención en Derecho penal, Madrid, Reus, 1981, traducción de F. Muñoz Conde, p. 87. Aun cuando concurran en la acción antijuridicidad y culpabilidad, la falta de reprochabilidad de esa acción y el que la ausencia de castigo de la misma no tiene efectos antipreventivos justifican la exoneración de responsabilidad penal. A lo que se suma que el autor pretendió con su acción preservar bienes jurídicos (cfr. ibid., p. 91).

40 C. Roxin, "El nuevo desarrollo de la dogmática jurídico-penal en Alemania”, cit., p. 12. 
merece una condena moral ${ }^{41}$. Lo hecho no es ni debe ser legal, pero si la concreta acción puede tener justificación moral, seguramente es más apropiado librar a ese concreto sujeto y en ese preciso caso de la pena ${ }^{42}$. Pues lo que no tendría mucho sentido es que se buscase el modo de exonerar de responsabilidad penal a quien hubiera torturado con maldad moral, sin excusa moral posible. 0 permítaseme expresarlo de una manera más: iacaso tendría sentido que se propusiera una causa de exclusión de responsabilidad penal para el torturador si la prohibición moral de la tortura se considerara absoluta?

Roxin, escribe también lo siguiente: hay que tomar en consideración la posible aplicación de una excusa supralegal de exculpación ${ }^{43}$, "pues se puede defender la tesis de que en los casos más extremos la prohibición absoluta de la tortura debe mantenerse, pero el castigo penal del salvador que se saltó la ley puede resultar absurdo. En la discusión -también la internacional- se debate sobre todo sobre las llamadas situaciones de bomba de relojería"44.

41 Tanto o más claro aparece ese punto en Kai Ambos: "Aunque sostener la prohibición de la tortura sea necesario para preservar la integridad y legitimidad de un Estado respetuoso de sus leyes, esto no es justo respecto de los oficiales de policía 0 agentes de seguridad individuales que pudieran encontrarse a sí mismos en situaciones donde la tortura es el único medio disponible para evitar un peligro serio para la vida humana (...). Sin embargo, este nivel individual, interesado en las categorías de culpa personal y culpabilidad, puede ser tenido en cuenta concediendo a estos oficiales una excusa en vez de una justificación" Kal AmBos, Terrorismo, tortura y Derecho penal. Respuestas en situaciones de emergencia, Barcelona, Atelier, 2009, p. 62

42 El mismo tratamiento propone Roxin para otro caso que pone sobre la mesa, el de un jefe de defensa aérea que derribara o hiciera que se derribara un avión con pasajeros que iba a ser utilizado por un terrorista que lo secuestró para provocar una catástrofe criminal como la de las Torres Gemelas. Sabido es que el Tribunal Constitucional Alemán, en 2001, declaró inconstitucional una ley que autorizaba dar orden para derribar el avión en un caso así. Pero al referirse a la posible responsabilidad penal de tal militar dice Roxin que seguramente procedería también aplicar una causa de "exclusión de la responsabilidad supralegal por ausencia de necesidades preventivas", teniendo en cuenta que, a la vez que se causaba la muerte de los pasajeros del avión (que en cualquier caso, añado yo, iban a morir poco después), dicho responsable evitó la muerte de otras muchas personas y "una cierta culpa existiría también cuando no hubiera salvado a las personas que gracias al derribo del avión podría haber salvado" C. Roxin, "El nuevo desarrollo de la dogmática jurídico-penal en Alemania", cit., p. 12.

43 Da la impresión de que en este punto Roxin ha evolucionado un tanto. En 2005 se expresaba más claramente en contra de que en el caso Daschner pudieran concurrir los requisitos para que se aplicara esa excusa supralegal, pero sí dejaba abierta la posibilidad de que concurriera en casos como los que se describen en el ejemplo de la bomba de relojería CFr. C. Roxin, "Kann staatliche Folter in Ausnahmefällen zulässig oder wenigstens straflos sein?", en Menschengerechtes Strafrecht. Festischrift für Albin Eser zum 70. Geburtstag, München, Beck, 2005, pp. 469-470.

44 C. Roxin, "Kann staatliche Folter in Ausnahmefällen zulässig oder wenigstens straflos sein?", cit., p. 468. En la teoría ética, una postura bien similar a la que tiene Roxin desde la dogmática penal fue 
Me parece que en Roxin están al mismo tiempo claras las razones para propugnar que el derecho no autorice la tortura en ningún caso, ni siquiera en esos en los que puede haber razones morales admisibles y en los que haya que buscar causas de exoneración de la pena para los que incurrieron en la ilegalidad. Dice Roxin que "si la tortura para la eliminación de un peligro [Folter zur Gefahrenabwehr] no se prohibiera para todo caso y de una vez por todas, sería difícil fijar límites que evitaran una progresiva extensión de tales prácticas" ${ }^{\prime 45}$, una ampliación de la tolerancia para torturar a cada vez más sujetos, incluidos los simples sospechosos. De esa manera se saldría del Estado de Derecho y se retornaría a la barbarie ${ }^{46}$.

Vale la pena echar un vistazo a las razones que Roxin brinda para defender la prohibición jurídica de la tortura en cualquier caso. Entre los juristas esas razones suelen ser o de tipo consecuencialista o de tipo deontológico. Las razones consecuencialistas son las que aluden a las consecuencias sociales perniciosas que puede acarrear que la tortura esté jurídicamente consentida en algún caso. Son los argumentos que de un modo otro se remiten a aquellas figuras de la pendiente resbaladiza o la ruptura del dique. Llamo razones de tipo deontológico a las que vienen a decirnos que el veto jurídico absoluto a la tortura se basa en que la tortura es moralmente un mal absoluto, un mal sin justificación moral posible en ningún supuesto.

En Roxin hay una mezcolanza de los dos enfoques. Razona que existe el peligro de que la más mínima tolerancia dé pie a un crecimiento paulatino de los supuestos

expuesta ya en 1978 por Henry Shue, en su clásico estudio "Torture", ya citado antes. Dice Shue que la teoría puede construir casos muy extremos (él utiliza el de un terrorista que ha colocado una bomba nuclear en París y que es interrogado para poder desactivarla antes de que estalle) y que muy difícilmente podrán ser nunca reales, pero para los que es poco menos que imposible negar la justificación moral de la tortura Cfr. H. SHuE, "Torture", cit., p. 57. Mas, según Shue, usemos el caso que usemos en la teoría moral, no se debe permitir que la prohibición jurídica de la tortura deje de ser absoluta, y quien hasta en un caso de aquellos tan raros cometiera tortura debe estar haciendo algo ilegal, aunque se pueda ver como justificado desde el punto de vista moral, como sucede, por ejemplo, con la desobediencia civil (cfr. Ibid., 58). Pero en cuanto a las consecuencias jurídicas para el autor en uno de eso supuestos, escribe Shue: "If the situation approximates those in the imaginary examples in which torture seems posible to justify, a judge can surely be expected to suspend the sentence" (ibid., p. 59). El problema y la tensión de fondo los retrata muy bien Allhoff cuando destaca que resulta muy chocante pensar en que penalmente se castigue a quien hace algo moralmente justificado, y que también se hace extraño pensar que, a ese en particular y en uno de aquellos hipotéticos casos extremos, se le castiga penalmente para evitar que se extienda en la sociedad la tortura moralmente injustificada" Fritz Alıнoff, "Torture Warrants, Self-Defense, and Necessity", Public Affairs Quarterly, 25, 2011, p. 219.

45 C. Roxin, "Kann staatliche Folter in Ausnahmefällen zulässig oder wenigstens straflos sein?", cit., p. 467.

46 Ibid., p. 468. 
permitidos y a una degeneración del Estado de Derecho en pura barbarie ilegítima; pero, al mismo tiempo, apela a la dignidad de la persona como supremo motivo. Si la tortura no puede legalizarse en ningún supuesto, es, según Roxin, porque daña esencialmente la dignidad humana. Pero no solo eso, también está en lo mismo la razón para que no puedan aplicarse a sus autores en ningún caso las eximentes de legítima defensa de un tercero o de estado de necesidad. No puede exculparse jurídicamente una acción del sujeto que mancilla de semejante manera la dignidad de la víctima, ya que no sólo se ejercería violencia contra su cuerpo, sino también contra su alma o esencia [nach Körper und Seele], convirtiéndola en puro objeto pasivo de la fuerza, tratándola como un puro instrumento u objeto y no como un ser humano. La dignidad humana no puede sujetarse a ninguna ponderación de intereses, ya que, como dice el art. 1 de la Constitución Alemana, es "unantatsbar", intocable ${ }^{47}$.

En consecuencia, según Roxin hay algo llamado dignidad, protegido sin reserva por la Constitución en su primer parágrafo y que no admite limitación o lesión bajo ninguna circunstancia, y por eso no puede estar justificada penalmente ni tener penalmente excusa ninguna acción que la menoscabe de manera grave, aunque sí hay que mirar si es aplicable una causa supralegal de exoneración de responsabilidad penal. Carezco de competencia suficiente para analizar si existe algo de incoherente en este juego entre lo que no es posible para las eximentes legales, pero sí, quizá, para las supralegales. Pero me quedan algunas dudas sobre el contenido y la función de la dignidad ${ }^{48}$. Al fin y al cabo, recordemos que uno de los primeros comentaristas del art. 1.1 de la Ley Fundamental de Bonn, G. Dürig, decía que ese estatuto supremo de la dignidad hacía que jamás de los jamases pudiera ser constitucional, en Alemania y bajo esa Constitución, una norma legal que permitiera la inseminación de una mujer con semen que no sea de su marido. Eso lo escribía Dürig allá por 1958.

Me limitaré a poner un ejemplo que, poco más o menos, he visto más de una vez en algún autor anglosajón. Supóngase, presuponiendo conocimiento cierto y seguro de cada extremo, que A y $B$ han secuestrado a un grupo de inocentes para torturarlos. Se turnan para infligirles horrorosos padecimientos. A es detenido mientras B está cumpliendo su tarea de torturador. Pero A no dice dónde están B y los secuestrados y empíricamente no queda más recurso que someterlo a tortura, si se quiere acabar con la tortura de los inocentes. ¿Se ponderan intereses ahí,

47 C. Roxin, "Kann staatliche Folter in Ausnahmefällen zulässig oder wenigstens straflos sein?", cit., pp. 465-466.

48 Sobre lo muy indeterminado del concepto y sobre el hábito de trivializarlo o darle una impronta puramente emotiva en la argumentación jurídica y iusfilosófica, véase Eric Hilgendorf, “Folter im Rechtsstaat?", Juristen Zeitung, 2004, p. 337. 
donde el ataque a la dignidad humana está por un lado y por otro del caso ${ }^{49}$, o no se tortura y se permite que sigan siendo aquellos inocentes tratados como objeto sin humanidad?

Entiéndase lo que planteo. Desde luego, no trato de dar argumentos para la legalización de ninguna forma de tortura en ninguna ocasión, sino nada más que de resaltar que el fundamento que Roxin ofrece para que no puedan jamás aplicarse las eximentes de legítima defensa de tercero o de estado de necesidad adolecen de un esquematismo, dogmatismo o apriorismo algo parecido al que muestran los que sostienen el carácter absoluto de la prohibición moral. En otras palabras, me convence fuertemente la parte consecuencialista del razonamiento de Roxin, pero no tanto esa superficial apelación al axioma de la dignidad, aquí como axioma jurídico con raigambre moral.

Los defensores del carácter absoluta e incondicionalmente inmoral de toda tortura, sean cuales sean sus circunstancias, formas y efectos sobre el torturado o sobre terceros, se oponen frontalmente no solo a cualquier legalización (en esto coinciden con la gran mayoría de los críticos de ese absolutismo moral), sino al juego de cualquier causa de exoneración de responsabilidad penal por su acción para el autor de cualquier tortura ${ }^{50}$. Hemos visto hace un momento que no es ese el caso de Roxin. Tampoco de otra buena parte de la doctrina penal. Por el contrario, puede razonablemente pensarse que quienes admiten, aunque sea muy excepcionalmente, que pueda concurrir, en lo penal, alguna causa de justificación están asumiendo

49 En la doctrina penal y iusfilosófica alemana, ese es un argumento que usa Hilgendorf, que subraya que puede haber un exacto paralelismo entre el padecimiento de la dignidad del culpable torturado y de la víctima secuestrada por él, por ejemplo, y que así como la Constitución alemana indica que la dignidad es inatacable, también dice que el Estado está obligado a protegerla E. HıLGendorF, "Folter im Rechtsstaat?", cit., pp. 337, 338 y 339.

50 Un ejemplo de tantos, en la doctrina penal alemana, lo brinda Jäger: "es indiscutible que la aquí defendida prohibición absoluta de tortura puede, en casos extremos, acarrear la consecuencia de que se pierdan numerosas vidas humanas, debido a que quizá no se consigan a tiempo informaciones que puedan salvarlas. Pero la conservación de la dignidad del Estado es un fundamento que justifica que ese alto precio se haya de pagar, llegado el caso. No se debe perder de vista que con la cuestión de la tortura lo que en verdad se está planteando es la cuestión del significado del Estado de Derecho, y precisamente por eso una justificación de la tortura no puede admitirse ni siquiera en los casos extremos" Chr. JäGeR, "Das Verbot der Folter als Ausdruck der Würde des Staates", cit., pp. 550551. Similarmente, Prittwitz insiste en que, si no se quiere que el Estado degenere en totalitarismo y deslegitimación, no se debe perder el carácter de tabú de cualquier forma de tortura y hasta de la mera amenaza de tortura, por lo que la prohibición jurídica tiene que seguir siendo radical y absoluta Cfr. Connelius Prittwitz, "Strafwürdigkeit und Strafbarkeit von Folter und Folterandrohung im Rechtsstaat", en Strafrecht zwischen System und Telos. Festschrift für Rolf Dietrich Herzberg zum siebzigsten Geburtstag, Tübingen, Mohr Siebeck, 2008, p. 519. 
que esa conducta penalmente justificada no será, en ese caso y para ese concreto sujeto, una conducta inmoral o carente de cualquier justificación moral posible.

En España, Llobet Anglí ha defendido recientemente que en un supuesto como el de la bomba de relojería debería jugar la eximente de legítima defensa, en su variante de legítima defensa de tercero. Esta autora subraya su oposición a cualquier legalización del torturar y resalta que el vincular los casos de ticking bomb con las torturas infligidas en la guerra contra el terror en lugares como Abu Ghraib es "hacer trampas" ${ }^{51}$. Sus razones pueden resumirse así:

a) Los requisitos de la legítima defensa, bien aplicados, "impiden, precisamente, la existencia de una política sistemática de torturas indiscriminadas, como medio para alcanzar mayor eficacia en la lucha contra el terrorismo", y los límites legales y doctrinales de esta causa de justificación hacen imposible la temida "ruptura del dique" 52 .

b) La legítima defensa "sólo permite reaccionar contra los autores (o partícipes) del ataque, es decir, contra los agresores" ${ }^{\prime 53}$. Y, en cuanto a la por muchos alegada incertidumbre sobre los resultados, "la legítima defensa no requiere que haya seguridad absoluta de salvación" 54 .

c) La concreta acción sólo justifica, como legítima defensa, “cuando no exista una posibilidad menos lesiva de obtener el mismo resultado"55.

d) Son de aplicación "los límites ético-sociales a la legítima defensa", empezando por el requisito de que no haya una escandalosa desproporción ${ }^{56}$.

La teoría jurídica no es ajena a las paradojas y las aporías, y esto bien lo saben los penalistas. Me permitiré jugar con un ejemplo ${ }^{57}$ que puede suscitar alguna perplejidad entre juristas, aunque no solo entre juristas.

51 "¿Es posible torturar en legítima defensa de terceros?", cit., p. 37.

52 Ibid., p. 28. En particular, dice esta autora, no cabe aplicar la legítima defensa a ningún tipo de tortura preventiva o que se anticipe netamente a la agresión (ibid., p. 29).

53 Ibid., p. 30.

54 Ibid., p. 32. "Si, por ejemplo, un policía abate a tiros a un sujeto que está intentando matar a una tercera persona, pero el agresor, antes de morir, consigue de todos modos su objetivo, la conducta del agente también está justificada" (ibid., p. 32).

55 Ibid., p. 32.

56 Como pasaría por ejemplo, si se torturase para impedir un delito contra el patrimonio (vid. ibid., p. 32).

57 El ejemplo está inspirado en el que maneja Wolfgang Mitsch en un magistral y densísimo trabajo, trabajo en el que plantea desde un punto de vista dogmático-penal variadas cuestiones de las que voy a mencionar a continuación. Vid. Wolfgang Mitsch, "Verhinderung lebensrettender Folter", en Strafrecht als Scientia Universalis. Festschrift für Claus Roxin zum 80. Geburtstag am 15. Mai 2011, Berlín, de Gruyter, 2011, pp. 638-655. 
Un sujeto ha secuestrado a veinte personas y las tiene encerradas en un lugar en el que, si alguien no aparece y lo evita, van a morir por falta de aire dentro de unas pocas horas. El secuestrador ha sido detenido y la policía sabe todo menos el lugar en el que están los secuestrados. Imaginemos incluso que el secuestrador ha dado todos los detalles, salvo la ubicación de aquel escondite. El jefe de la policía ordena que lo amenacen con las más cruentas torturas y que, si no cede a la amenaza, comiencen a aplicarle medidas que le causen dolor, incrementando la dureza de las mismas cada diez minutos. Son tres los policías de ese equipo. Uno de ellos, P, al ver que la primera fase de la tortura va a comenzar, saca su arma y amenaza a los otros para evitarlo. Puesto que el propósito claro de la acción de P es el de impedir un delito tan grave como el de la tortura, idirían los penalistas (0, al menos, los que mantienen que ninguna causa de justificación es aplicable en ningún caso a tortura alguna) que a ese policía que amenaza a los otros para que no torturen se le aplica una eximente de estado de necesidad o de legítima defensa de un tercero?

Imaginemos algo más. En las circunstancias del caso, lo único que podía hacer P para que sus compañeros no ejecutaran el delito de torturar era amenazarlos para que se mantuvieran quietos durante cinco horas. Exactamente las horas que tardarían y tardaron los secuestrados en morir en el escondite. ¿Sigue concurriendo la causa de justificación en favor de $\mathrm{P}$ y en lo que tiene que ver con la calificación penal de su acción frente a sus compañeros? ¿Y pude imputarse a $P$ alguna responsabilidad penal por la muerte de los veinte secuestrados y por haber impedido él violentamente lo que los alemanes llaman "Rettungsfolter" o tortura para salvar?

$Y$ aun podemos complicarnos otro poco. Los compañeros de $P$ deciden ignorar su amenaza y siguen adelante. P les dispara y los va matando o hiriéndolos para incapacitarlos, ya que no ceden en su propósito de torturar al detenido. ¿Siguen amparando a $\mathrm{P}$ alguna eximente? No podrán decir los defensores de la prohibición moral absoluta y de la no concurrencia de ninguna causa de justificación penal en ningún supuesto de tortura que es desproporcionada la acción de P, pues ellos asumen que el ataque a la dignidad de la persona es más grave si se la tortura que si se la mata, y de ahí que quepa matar en legítima defensa o en estado de necesidad, pero no así torturar.

Es muy tremenda esa situación y pone en jaque la consistencia de las doctrinas jurídicas (y las morales), porque, aun partiendo de que la tortura es delito, y también la "Rettungsfolter", tenemos:

a) Que los que consideran que no puede concurrir ninguna causa de exclusión de la responsabilidad penal ni siquiera en el caso más extremo de "tortura de salvación", se van a ver en un gran apuro para no tener que conceder que sí concurre 
una eximente penal en el que mata al torturador para que no torture al secuestrador que sabe dónde están los secuestrados en inminente peligro de muerte, y que tampoco tiene ninguna responsabilidad penal por la muerte de esos rehenes. Es decir, P impidió la tortura del secuestrador al precio de matar a sus dos compañeros policías (no había, en la situación, una medida posible más leve para evitar la tortura, concedamos eso) y al precio de excluir la salvación de los veinte secuestrados, pero P no puede ser penalmente castigado. Lo curioso es que si P no hubiera hecho nada o se hubiera limitado a incumplir su parte de las órdenes y no colaborar en la tortura, P ni habría cometido delito ni tendría sobre su conciencia ninguna muerte.

b) Sabemos que otros creen que sí puede concurrir para el torturador, en tales casos extremos, alguna causa de exención de la responsabilidad. Entonces $P$ habrá matado a dos compañeros suyos que incurrían en una conducta penal típica, pero para la que tenían una causa que penalmente los justificaba. ¿Dirían esos autores que P está penalmente justificado aunque, para evitar la tortura del secuestrador, haya matado a los que estaban penalmente justificados al torturar para salvar a aquellos veinte? ¿Y lo estará aunque $P$ supiera que con su acción no sólo evitaba la tortura de uno, sino también la salvación de los veinte que al final efectivamente murieron?

c) Ahora dejemos el plano jurídico y preguntémonos por normas y responsabilidades morales. Desde el punto de vista estrictamente moral, iactuó bien 0 actuó mal P? 0 muy equivocado estoy, o me parece que los que propugnan el carácter absoluto, incondicionado y sin excepción posible de la prohibición moral de la tortura deben concluir que P obró bien al evitar la tortura del secuestrador y a ese precio, si es que un precio menor no cabía para ese fin. Porque si mantienen lo contrario, contradicen su tesis sobre el carácter absoluto del veto moral a la tortura. No es que $P$ haya evitado el mal mayor, ya que ese deontologismo extremo no deja sitio a cálculos de ese tipo. Es que si la prohibición moral de torturar es absoluta e incondicionada, igual de absoluta e incondicionado ha de ser el reverso de esa prohibición, la norma moral que manda evitar la tortura cuando sea posible evitarla y al precio que haga falta para evitarla. Si A, que puede torturar al secuestrador para salvar a veinte de una muerte segura no debe torturar, en el caso de que B pueda evitar que A torture debe evitarlo igualmente, aunque sea con el coste de aquellas veinte vidas $0 . .$. , de la vida misma de $A$. Porque ya se ha insistido aquí varias veces en que a esa conclusión arribamos si consideramos que moralmente nunca puede estar justificada la tortura, pero que moralmente sí puede estar justificado el matar a otro en casos de legítima defensa o de estado de necesidad.

Moralmente no estaba A legitimado en ningún caso imaginables para torturar al secuestrador con el objetivo de evitar la muerte de los veinte secuestrados, pero 
los mismos absolutistas morales que tal afirman concederán generalmente que $A$ sí estaba moralmente autorizado a matar al secuestrador si con eso aseguraba la salvación de los inocentes y no había otro camino para tal fin. A puede matar al secuestrador para salvar a los inocentes, pero B puede matar a A para salvar al secuestrador de la tortura y aunque con seguridad vayan a morir los secuestrados inocentes. Ahí resalta en su plenitud la paradoja del absolutismo moral en este tema.

\section{El ejemplo de la bomba de relojería y sus críticos}

Son muchos los autores que se han opuesto a ese ejemplo, ejemplo que está emparentado con alguno que ya usara Bentham, que empleó M. Walzer en $1972^{58}$ y que ha reaparecido con fuerza en las obras de algunos actuales defensores de la legalización de la tortura en determinados supuestos, como Dershowitz. Como nos recuerda Oren Gross, el escenario hipotético de la bomba de relojería supone un importante reto teórico para los que insisten en el carácter absoluto, incondicionado y sin excepciones de la prohibición moral de torturar y hasta piensan que intentar una conversación racional sobre la tortura puede resultar dañino, pues puede socavar la convicción sobre el carácter radical de la prohibición ${ }^{59}$.

No pretendo manejar ni citar todos los tratadistas que se han ocupado del tema, pero sí hacer una clasificación y síntesis de las críticas más frecuentes.

\subsection{Sobre las condiciones epistémicas de los casos}

Como dice Waldron, "Muchos de esos casos hipotéticos sobre la bomba de relojería no son nada realistas y emplean nada realistas estipulaciones sobre conocimientos y efectos" 60 . Mencionemos algunos ejemplos de este tipo de críticas.

Según David Luban, el escenario de la bomba de relojería "va unido a una serie de presupuestos, cada uno de los cuales es de una u otra manera improbable y que, tomados en conjunto, son absolutamente improbables"61. Henry Shue explica que en las situaciones reales la tortura es inexcusable, por mucho que podamos

58 En su artículo "Dirty hands and ordinary life", Philosophy and Public Affairs, 2, 1972, pp. 160-180. Walzer lo emplea al hablar de las decisiones que a veces pueden tener que tomar los políticos y que son contrarias a la moral ordinaria de los ciudadanos.

59 Oren Gross, "The Prohibition on Torture and the Limits of Law", en Sanford Levinson, Torture. A Collection, Oxford, Oxford University Press, 2004, p. 230.

60 J. Waldron, "What are moral absolutes like", cit., p. 6.

61 David Luban, "Unthinking the Ticking Bomb", en: Ch.R. Beitz, R. E. Goodin -eds.- Global Basic Rights, Oxford University Press, 2011. Aquí cito por la version digital en: http://Isr.nellco.org/georgetown/ fwps/papers/68, p. 7 
imaginar ejemplos hipotéticos en los que la excusa moral quepa. En los supuestos de la bomba de relojería se incurre en idealizaciones y abstracciones que deforman toda posible realidad, mejorándola y eliminando de la consideración precisamente las circunstancias que en la realidad siempre comparecen y que hacen inaceptable la tortura. De esa manera, lo hipotético se vuelve superior a lo real y de lo hipotético se sacan conclusiones para lo real, con consecuencias desastrosas ${ }^{62}$. Christopher Tindale abunda en que la concurrencia cierta de las condiciones que, como presupuestos epistémicos, se ponen en el ejemplo de la bomba, en la práctica solamente se podrá comprobar a posteriori, una vez que la tortura ha sido infligida a quien se creía (a lo mejor erróneamente) que..., teniendo en cuenta también que la incertidumbre será tanto mayor cuanta mayor sea la urgencia y presión con que la policía actú $e^{63}$.

Se podría replicar que el ejemplo vale para lo que vale y no pretende valer para lo que no vale. Quiero decir que el ejemplo no se construye para un caso en que la policía cree que concurren condiciones (que el detenido sea el culpable de poner la bomba, que no haya otra manera de evitar que la bomba estalle, que van a morir inocentes si estalla...), sino para un caso en que la policía sabe que concurren tales condiciones. El teórico que trae el supuesto hipotético de la bomba no dice que esté justificado torturar cuando se piensa que el detenido puede tal vez ser el que... Que todo saber con la requerida certeza puede, sin embargo, ser un saber erróneo es algo que también se asume cuando un juez penal condena a alguien por un delito y sobre la base de considerar la autoría probada más allá de cualquier duda razonable.

Creo que existe aquí lo que se puede llamar un desajuste metodológico. Cuando tenemos que resolver un problema práctico y real y razonamos sobre él, las circunstancias que tenemos que manejar son las que son, nos vienen dadas y no las planteamos nosotros. Si alguien competente, E, tiene que dictaminar moral o jurídicamente si A mató a B en legítima defensa, deberá averiguar unas cuantas cosas decisivas para poder decir si en ese caso concurre o no dicha excusa moral 0 eximente jurídica. Cuestión distinta es si a ese experto, E, le preguntamos acerca de si puede existir algún caso en que una persona que mate a otra esté disculpada por

62 Henry Shue, "Torture in Dreamland: Disposing of the Ticking Bomb", Case Western Reserve Journal of International Law, 37, 2006, p. 231. Está en este artículo de 2006 corrigiendo o matizando su propio uso de tales casos en su artículo "Torture", de 1978.

63 Christopher W. Tindale, "Tragic Choices: Reaffirming Absolutes in the Torture Debate", International Journal of Applied Philosophy, 19, 2005, pp. 212-213. Similarmente se expresa David Luban, "Liberalism, Torture, and the Thicking Bomb", en Karen J. Greenberg, The Torture Debate in America, Ney York, Cambridge University Press, 2005, p. 45. 
obrar en legítima defensa. Entonces, él puede construir un supuesto a su antojo, un caso imaginario en el que las circunstancias concurrentes sean con claridad las que configuran esa excusa.

Ahora bien, cuando $\mathrm{E}$ nos brinda ese caso $\mathrm{K}$ de su cosecha con el que quiere ilustrarnos, podemos dar por sentadas dos cosas, dos cosas que se siguen de esa exposición suya. Una, que no cree que la prohibición de matar sea absoluta e incondicionada, ya que admite que pueda haber casos en que sea admisible (moral 0 jurídicamente, según el sistema normativo en el que nos estemos moviendo) matar a otro, siendo uno de esos casos cuando concurra la legítima defensa. Otra, que en ese ejemplo que él nos ha presentado como típico concurre la excusa de legítima defensa. Podemos entender, pues, lógica en mano, que E está diciendo que habrá legítima defensa y, con ello, justificación para matar en todos los casos que sean perfectamente iguales a $\mathrm{K}$ y todos los casos que tengan las propiedades de $\mathrm{K}$ que son relevantes para que comparezca la excusa legítima defensa. Lo que en modo alguno le podemos imputar a $\mathrm{E}$ es que con su ejemplo (mediante el que nos dice que sí puede haber homicidios justificados por legítima defensa y que un ejemplo de esos homicidios es $\mathrm{K}$ o cualquier caso que tenga las propiedades a esos efectos relevantes de K) nos esté indicando que cualquier caso posible de homicidio puede estar justificado por legítima defensa o que puede ser así justificado cualquier caso que tenga alguna coincidencia relevante con $\mathrm{K}$ y no todas las notas relevantes de $\mathrm{K}$.

Que las condiciones epistémicas de ejemplos como el de la thicking bomb no sean creíbles o reales simplemente indica que en la práctica y en la realidad de los hechos no vamos a toparnos con casos en los que pueda estar justificada la tortura, si nada más que dicha justificación se apoya en tal argumento, en esos ejemplos. Pero no es porque los ejemplos no puedan ser justificativos, sino porque no pueden hacerse realidad. Esto significa que no es lo mismo decir que la prohibición moral de hacer $\mathrm{X}$ es absoluta, que decir que no es absoluta y puede tener excepciones, aunque esas excepciones es casi imposible que concurran. Si son posibles excepciones, aunque no sea más que en plano teórico o especulativo, la prohibición moral de $\mathrm{X}$ no es absoluta.

A mí me pueden preguntar qué haría si en alguna lotería me tocaran cien millones de euros y yo puedo contestar que lo más apropiado me parecería comprarme una cómoda casa en los Alpes suizos y llenarla de libros. Entonces alguien replica que no es real que a mí me gusten los Alpes, las casas y los libros, ya que es sabido que no juego a ninguna lotería y que, en consecuencia, nunca tendré un premio así. Ese es un razonamiento erróneo. Porque a mí no me preguntaron qué voy a hacer cuando me toquen cien millones en la lotería, sino qué haría si me tocaran cien millones en 
la lotería (en la hipótesis, asumida en una pregunta así, de que jugara a la lotería). Además, que yo no haya jugado nunca a la lotería no significa que no pueda jugar mañana por primera vez y que no pueda verificarse pasado mañana una hipótesis que hasta ahora, en lo que a mí se refiere, era inverificable.

Si las condiciones con que se diseña el ejemplo de la bomba, para el cual ly solo para el cual y bajo esas condiciones) dice alguien que estaría justificada moralmente la tortura, no se van a dar en la realidad nunca, la preocupación desaparece: nunca va a estar justificada la tortura. Frente al absolutista moral, lo único que se estaba diciendo es que, sobre el papel o a título de hipótesis no ontológicamente imposible, puede haber un caso en que torturar sí estuviera moralmente justificado, cosa que por definición el absolutista niega ${ }^{64}$. Pero no lo niega el absolutista por razón de la improbabilidad de esas condiciones, sino porque es a absolutista y, como tal, lo descarta tanto si esa tesitura es mucho, poco o nada probable.

Ahora bien, si de probabilidades hablamos..., cuántas sorpresas hemos recibido. Quien hubiera inventado en algún tratado de ética o filosofía política el derribo de las Torres Gemelas habría sido tachado de loco por querer concluir a partir de una hipótesis poco menos que inviable. Y ocurrió.

Así pues, pongamos que yo no estoy diciendo que sea probable que ocurra el caso de la bomba (o cualquier de los ejemplos o versiones que se han utilizado del mismo), sino preguntándome si sería moralmente legítimo torturar a aquel sujeto si milagrosamente ocurriera. Porque no estoy atacando la aversión a la tortura 0 su prohibición, sino poniendo a prueba al absolutista moral en este campo. Y si yo concluyo que en ese caso, y solo en ese, es moralmente aceptable la tortura, nada estoy expresando sobre casos distintos y en los que cambie una sola de las condiciones definitorias de este. Y no cambia ni un ápice mi aversión a cuantos torturaron en Afganistán, Chile, España, Argentina, la Unión Soviética, Camboya, la Alemania Nazi, Siria o cualquier otro lugar del mundo. Pues seguro, además, que nunca lo hicieron ante un caso estructuralmente análogo al de la bomba de relojería.

En el razonamiento teórico sobre temas morales o políticos (y hasta jurídicos) los mejores y más agudos autores muy a menudo trabajan con las que tradicionalmente se llaman hipótesis de escuela. Es una herramienta bien útil para poner a prueba la

64 Esas diferencias las ve bien, por ejemplo, Allhoff, quien subraya que si el crítico cambia las condiciones epistémicas del caso de la bomba de relojería, no está respondiendo a si moralmente estaría justificada la tortura en ese caso, por improbable que sea, y está refiriéndose a otros casos respecto de los cuales el que plantea la justificación para el supuesto de la bomba puede fácilmente admitir que no habría excusa para torturar Fritz Alıhoff, "Ticking Time-Bombs and Torture", en A.I. Cohen, Chr. H. Wellman, Contemporary Debates in Applied Ethics, 2a ed., Wiley, 2014, p. 250. 
consistencia o resistencia de las teorías. Es el preguntarse qué se derivaría de esta teoría si..., en la hipótesis de que... ${ }^{65}$ Cuando alguien propone una hipótesis como instrumento de análisis (cuánto de triste me sentiría yo si mi mujer me abandonara mañana...) y el interlocutor contesta que eso nunca va a ocurrir en la realidad (tranquilo, sabemos que tu mujer nunca te va a abandonar, dice el otro), ese otro está en la misma situación que se predica de aquel que miraba el dedo cuando le señalaban la luna.

\subsection{Sobre los límites y problemas del consecuencialismo moral}

Se reconoce entre los críticos, no sin buena parte de razón, que al ataque al absolutismo moral mediante el ejemplo de la bomba le subyace habitualmente un planteamiento de moral fuertemente consecuencialista o utilitarista. Y es bien cierto que el consecuencialismo moral sin freno puede llevar a la justificación de todo tipo de barbaridades y excesos. Por eso los defensores de la ética utilitarista han ido afinando enormemente, de Mill y Bentham para acá, comenzando por la imprescindible diferenciación entre utilitarismo del acto y utilitarismo de la regla. Pero no entraremos aquí en tales debates sobre el utilitarismo.

Lo que en esta discusión sobre la tortura y la ticking bomb se hace una y otra vez es cambiar el ejemplo para que se aplique a otras situaciones la supuesta implacable lógica del caso de la bomba. Paso a citar algún ejemplo.

Escribe Stephen Holmes que la parábola de la bomba de relojería hace que la legitimidad de la tortura dependa completamente de sus consecuencias; a saber, de la prevención de un grave daño ${ }^{66}$. Catherine McDonald ${ }^{67}$ pide que consideremos el siguiente caso (es el conocido caso de los trasplantes) "lógicamente equivalente". Hay un conjunto de personas que, para seguir viviendo, necesitan urgentemente el

65 Como dice McMahan, “Los ejemplos hipotéticos sirven para algo que los ejemplos históricos raramente consiguen, como es filtrar los detalles irrelevantes que pueden desorientar 0 distraer nuestras intuiciones, y por eso nos hacen fijarnos precisamente en aquellos aspectos de los que hemos de examinar el significado moral". Agrega que, para ese uso, el ejemplo de la bomba de relojería es perfectamente equivalente a tantísimos otros que se han empleado y se emplean en la teoría ética, como pueda ser, recientemente, el muy comentado "trolley problem". Podríamos añadir, similarmente, el conocido problema del "fat man" o el llamado caso de los trasplantes, ambos introducidos y tratados por Judith Jarvis Thomson y discutidos por muchísimos después.

66 Stephen Holmes, "Is Defiance of Law a Proof of Success? Magical Thinking in the War on Terror", en Karen J. Greenberg, The Torture Debate in America, Ney York, Cambridge University Press, 2005, p. 128. Añade Holmes que de tal modo se quiere hacer ver, subliminalmente, que la tortura es la única respuesta posible ante el terrorismo (ibid., p. 128).

67 "Deconstructing Ticking-Bomb Arguments", Global Dialogue, 12, 2010, p. 4. 
trasplante de algún órgano vital. En unos es el hígado, en otros el corazón, etc. Si matamos a una persona sana, a una sola, y le extraemos sus órganos trasplantables, salvamos a esas personas en riesgo. Como los salvados son bastantes más de uno, las cuentas salen y estaría moralmente justificado ese homicidio del inocente.

Las diferencias parecen claras, más allá de que es obvio que con un razonamiento consecuencialista sin restricciones y burdo podemos justificar todas las salvajadas que se nos ocurran. En el caso de la bomba, y supuestas las condiciones epistémicas con que en sede teórica manejamos la hipótesis en cuestión, resulta que: a) el candidato a la tortura es el mismo que ha puesto en riesgo a los otros, lo cual no pasa en este caso de los trasplantes; b) el candidato a la tortura puede evitar con una sola acción suya (la confesión sobre el lugar donde puso la bomba) tanto la muerte de los inocentes como su propia tortura, lo cual tampoco le cabe al de los trasplantes.

No sé bien si la consideración de esas diferencias nos conduce a un consecuencialismo refinado y mucho más útil o a un razonamiento deontológico también más fino y argumentado que el del absolutismo a secas. Lo que sí sé es que el aceptar en un caso un razonamiento consecuencialista no fuerza a aceptar las consecuencias de cualquier razonamiento consecuencialista, por grosero que sea ${ }^{68}$. Así, en tema de justificación del castigo penal, un utilitarista penal puede defender que lo que justifica la pena es el efecto de prevención general positiva o negativa que tiene la condena del culpable, pero eso no le fuerza a asumir la típica objeción de que, entonces, también ha de aceptar la condena de un inocente cuando esa condena tiene los mismos efectos preventivo-generales, por ejemplo porque a los ciudadanos se les oculta celosamente que era inocente ese condenado.

David Luban ${ }^{69}$ invita a que consideremos el caso en que lo que se sabe es que si lo torturamos a usted, ciudadano inocente que se encuentra en el auditorio que aplaude una conferencia de Dershowitz, el terrorista confiesa dónde puso la bomba. Aunque yo no aplaudo a Dershowitz (conste eso), viene a ser como si Luban me

68 Explica McMahan que no estamos ante razonamientos puramente consecuencialistas, pues un razonamiento puramente consecuencialista permitiría, por ejemplo, torturar a un inocente, en lugar de al culpable, si el balance de consecuencias es más favorable. Dice que un razonamiento consecuencialista justificaría el torturar a un inocente durante cien minutos si esa es la única manera de evitar que otra persona torture durante ciento un minutos a otro igual de inocente. Para McMahan, el caso de la justificación moral de la tortura en supuestos excepcionales tan raros como el de la bomba es un caso de "lesser evil justification". Una "lesser evil justification" requiere "una diferencia sustancial entre el mal infligido y el evitado".

69 "Unthinking the Ticking Bomb", en: Ch.R. Beitz, R. E. Goodin -eds.- Globan Basic Rights, Oxford University Press, 2011. Aquí cito por la version digital en: http://Isr.nellco.org/georgetown/fwps/ papers $/ 68$, p. 16. 
preguntara a mí, cuestionador del enfoque de moral absolutista en este tema, si me parecería bien ser yo el torturado en el caso de la bomba y siendo yo inocente del todo. Varias ideas se me ocurren para replicar a Luban.

Primera. Aunque todos, y yo mismo, usamos con frecuencia en estos debates el vocativo o el estilo en segunda persona (qué le parecería a usted mismo si...), en el razonamiento moral hay que tener cuidado con las transiciones entre razonar en segunda y en tercera persona. Si, imaginariamente, Luban me pregunta a mí qué me parecería que se me torturara, siendo yo inocente del todo, para salvar a media ciudad de una bomba, es como si yo le pregunto a él si no estaría dispuesto a decir que sí a la tortura si esa es la única manera que queda para salvar la vida de sus hijos y toda su familia y que a ver si es coherente él ahí con su tesis general. No es un buen método para hacer teoría ética, pues con ese planteamiento se pone entre paréntesis uno de los elementos claves de la racionalidad moral, las condiciones de imparcialidad del razonamiento. Si yo les digo a los que me escuchan en una sala "qué harían ustedes si la mafia hubiera secuestrado y estuviera torturando a sus hijos pequeños y no tuviera usted más opción que matar a esos mafiosos para salvar y liberar a sus hijos" y los de la sala me contestan al unísono que matarían en ese caso, yo haré mal en concluir ante ellos, ufano, "iven cómo son ustedes partidarios de la pena de muerte en algún caso y ven cómo la pena de muerte puede tener justificación moral?". Yo habría incurrido en más de una falacia grave al razonar así.

Segunda. 0 tomamos en serio la verosimilitud de los ejemplos o no la tomamos. Pero con congruencia. Luban, como tantos, dice que el escenario de la bomba de relojería es por completo inverosímil, empezando por las condiciones epistémicas (se sabe con plena certeza que...) y que, por consiguiente, nada válido para la práctica se puede sacar de él. En eso puede que tenga bastante razón; lo cual, en mi opinión, indica que nunca o casi nunca estará en la práctica y la vida real moralmente justificada la tortura, aunque puede servir aquel ejemplo para atacar el absolutismo moral, que es de lo que aquí estamos hablando. Mas si el escenario que dibujan Dershowitz \& Cia no sirve, por inverosímil, para sostener sus conclusiones, tampoco escenarios igual de inverosímiles o más y variaciones del caso de la ticking bomb valdrán para reforzar las tesis contrarias, como la de Luban.

Tercera. Insisto en que decir consecuencialismo no es igual que decir cualquier consecuencialismo. Y en que hasta para los puros utilitaristas un cambio en los datos puede alterar el resultado del cálculo. En lo que importa para lo que estamos tratando en este punto, los datos relevantes del caso de la ticking bomb son que el detenido es culpable y que el detenido puede evitar la explosión de la bomba (y su propia tortura) dando la información correspondiente. En el caso alternativo de Luban no se cumple 
ninguna de esas dos condiciones, pues el torturado es un inocente y no puede ese inocente proporcionar la información, sino que depende de que, al verlo torturado a él, la dé el terrorista. Apenas se me ocurren utilitaristas sofisticados dispuestos a avalar una justificación utilitarista en ese caso, fundamentalmente porque no la respaldaría un utilitarismo de la regla, que es el único que puede funcionar con algo de racionalidad en situaciones tan complejas.

Por otra parte, Bufacchi y Arrigo apelan al propio esquema consecuencialista para hacer ver que, sean cuales sean las consecuencias positivas que surta el torturar en el caso de la bomba de relojería, son mayores los efectos negativos que arrastra la institucionalización estatal de la tortura, su autorización y la preparación de los aparatos estatales (médico, científico, policial, militar y legal) para aplicarla ${ }^{70}$. “Cualquier estado que establezca unidades de interrogación con tortura perderá su legitimidad moral y degradará la obligación política de sus ciudadanos"71, agregan. Pero ese es un buen argumento contra los que quieran pasar de la posible justificación moral en algún caso a la autorización jurídica para la tortura en ese tipo de casos 0 en otros, no contra tantos que solamente afirman que puede haber en alguna oportunidad justificación moral, pero que no debe darse jamás institucionalización ni permiso jurídico ${ }^{72}$. Los autores están debatiendo con las peculiares pretensiones jurídicas de Dershowitz ${ }^{73}$, no con los antiabsolutistas morales que no quieren la legalización. Pues los que nada más que se oponen al planteamiento absoluto de la prohibición moral pueden y suelen estar de acuerdo en que las consecuencias de cualquier legalización de la tortura pueden ser catastróficas también.

\subsection{Sobre las intenciones de los tratadistas}

No son ciertamente escasos los expositores que combaten el ejemplo de la bomba de relojería, y su posible utilización para cuestionar el absolutismo moral en materia de tortura, aduciendo aviesas intenciones de los propagadores de tal

70 V. BufacchI, J.M. Arrigo, "Torture, Terrorism and the State: a Refutation of the Ticking Bomb Argument", Journal of Applied Philosophy, 23, 2006, pp. 360ss., pp. 362ss. Muy similarmente, B. BRECHER, Torture and the Ticking Bomb, Oxford, Blackwell, 2007, pp. 41ss.

71 V. Bufacchi, J.M. ArRigo, "Torture, Terrorism and the State: a Refutation of the Ticking Bomb Argument", cit., p. 366.

72 Entre los expositores en que con más claridad y contundencia está expresada ese enfoque, y por citar uno más, está Oren Gross. Véase su trabajo "The Prohibition on Torture and the Limits of Law", cit. Esa tesis se enuncia ya en p. 231 y se desarrolla en el resto del artículo.

73 Vid. V. Bufacchi, J.M. Arrigo, "Torture, Terrorism and the State: a Refutation of the Ticking Bomb Argument", cit., pp. 365ss. 
ejemplo. Detrás de ese supuesto imaginario estaría sencillamente una intención de justificar la tortura a secas y en muchos más casos; 0, peor todavía, latiría en el fondo el ánimo de disculpar las políticas indeseables de la Administración Bush en países como Iraq y su sucia utilización de la tortura ${ }^{74}$.

Algún ejemplo. Escribe David Luban que "el caso de la bomba de relojería es traído a colación contra los liberales que creen en una prohibición absoluta de la tortura. La intención es la de forzar al liberal prohibicionista a admitir que sí, que está de acuerdo con la tortura en al menos esa situación. Una vez que el prohibicionista ha admitido eso, ha concedido que su oposición a la tortura ya no está basada en un principio. Una vez que el prohibicionista ha admitido que su principio moral puede ser derrotado, todo lo que queda es discutir el precio. El prohibicionista ya no puede invocar su elevado fundamento moral, ya no puede atribuirle a su oponente la carga de la prueba"75. Con el mayor respeto y sin querer pecar de incorrecto en exceso, el argumento me recuerda aquel viejo refrán de "mujer besada, mujer ganada".

Pero en el fondo el argumento habla de intenciones. Es más que verosímil que, en efecto, sean torcidas y no plenamente confesadas las intenciones de muchos de los que apelan al ejemplo de la bomba de relojería para sustentar la posible justificación moral de la tortura en alguna oportunidad. Puede que bastantes sean ultraconservadores y cómplices de lo más reaccionario y brutal de la política norteamericana (o neonazi o stalinista o maoísta o...). Pero no son todos así y, sobre todo, no estoy convencido de que el valor en sí de un argumento, en sede teórica, esté radicalmente condicionado por las intenciones prácticas de estos o aquellos que lo utilizan ${ }^{76}$. Complementariamente, tampoco comprendo bien por qué la toma seria en consideración, como argumento contra el absolutismo moral, de ese ejemplo revitalizado por Dershowitz (pero antes por Walzser o Shue o muchos más), nos hace por necesidad cómplices de las intenciones de dicho autor o compañeros de viaje de sus maniobras políticas o jurídicas. Las comparaciones y ejemplos para sostener lo contrario podrían ser infinitos. Yo en verdad no soy religioso ni profeso gran simpatía a la Iglesia Católica, pero no tengo por qué negarle valor moral al ejercicio de la caridad bien entendida con el prójimo por el hecho de que la Iglesia una y otra vez

74 Así lo insinúa, por ejemplo, Catherine McDonald en "Deconstructing Ticking-Bomb Arguments" cit., p. 2.

75 David Luban, "Liberalism, Torture, and the Thicking Bomb", cit., p. 44.

76 Como explica Frances M. Kamm, importa recordar que el mostrar que la tortura puede ser moralmente permisible en algún caso "no tiene por qué implicar que fuera permisible alguna tortura aplicada por Estados Unidos o sus aliados" F.M. Kamm, Ethics for Enemies. Terror, Torture and War, cit., p. 5. 
insista en el mandato de caridad. Otro ejemplo: es como si yo o alguno dijera que, puesto que los que defienden el carácter absoluto de la prohibición moral de la tortura dan la razón a cuantos absolutistas morales ha habido (dictadores, líderes religiosos, etc.) se hacen cómplices de todos los absolutismos morales habidos 0 por haber. No es justo. No tiene sentido, por ejemplo, imputar tales intenciones o tal inconsciente complicidad a autores como Waldron, entre otros muchos. Se puede abogar por la donación de sangre sin ser simpatizante de Drácula.

\subsection{Sobre un peculiar enfoque consecuencialista}

Hay un razonamiento bastante común en los críticos del caso de la bomba y en quienes cuestionan que ni siquiera como hipótesis quepa plantear excepciones a la prohibición moral absoluta de torturar, ya esté ese razonamiento desarrollado 0 ya se insinúe apenas. Se trata de apuntar que el admitir en sede teórica la justificación moral para el caso de la bomba de relojería tendrá la consecuencia más que probable de que, una vez entreabierta esa puerta, vayan siendo más los casos que se quieran moralmente justificados, hasta acabar dando prácticamente una carta moral en blanco a los torturadores. Es mejor negar todo posible fundamento moral a la tortura en cualquier caso, hasta en el más raro de los imaginables, puesto que si se concede lo más mínimo en el plano de la teoría moral, se acaba dando alas a los que quieren su autorización y regulación jurídica para multitud de supuestos. Por consiguiente, no sería tanto que no haya respetables argumentos para la justificación moral en el supuesto de la bomba y asumidos los presupuestos epistémicos y las circunstancias extremas y raras del mismo, sino que más vale que ni lo razonable se conceda, si no queremos regalar, a la postre, patente de corso a los torturadores. Las consecuencias objetivas, pues, de admitir tal justificación para un caso acabarían siendo desastrosas para todos o para muchos casos.

También en esa manera de razonar hay algo de falaz, desenfocado e incongruente. Se quiere bloquear la disquisición teórica en ese punto y se propone ya no un absoluto moral que se pretenda y se pueda justificar, sino un tabú teórico. El lema sería el de "mejor no removerlo", pues si en la teoría lo remueve el tratadista bien intencionado o que nada más que busca poner a prueba las tesis teóricas, otros, los políticos, acabarán aprovechándose para sus fines perversos. Viene a ser como si un enemigo radical de cualquier posible justificación moral del aborto en algún caso alegara que no se puede ni permitir que otro plantee si algo de justificación moral cabe para el aborto en caso de violación o malformación muy grave del feto (presuponiendo, además, el cumplimiento de otras condiciones muy estrictas), con 
el argumento de que se empieza examinando esos supuestos, que quizá podrían ser razonables, y se acaba en el aborto libre o nada más que sometido a plazo.

Nos resultará familiar el razonamiento, ya que es el habitual en quienes se resisten radicalmente a cualquier justificación moral de la eutanasia y cuentan que por mucho que los partidarios digan que la justificación cabría nada más que bajo condiciones sumamente precisas (enfermedad terminal, gran sufrimiento, voluntad claramente manifestada...), lo que en verdad consiguen todos esos que presentan los ejemplos extremos es dar facilidades para que se acabe matando a cualquier enfermo que nos moleste.

\subsection{Quizá haya una eximente, pero no hay una justificación}

Michael Davis, en uno de los trabajos más citados sobre el problema moral de la tortura, escribe que lo que muchos de los que admiten la tortura en algún caso están haciendo patente es que puede haber una "moral excuse", no una justificación77. Es un argumento un tanto rebuscado. Todo depende, por supuesto, de cómo queramos definir "justificación" y "eximente". Aquí la filosofía moral tendría bastante que aprender, en lo conceptual, del Derecho penal; por ejemplo, de la distinción entre antijuridicidad y culpabilidad.

Los que cuestionan el carácter absoluto de la prohibición moral78 no tratan de explicar el caso en que el policía, en el supuesto hipotético de la bomba de relojería (y bajo las condiciones epistémicas precisas con que el caso se dibuja), cometa un ilícito moral, pero sea personalmente excusable, por ejemplo porque no tenía en ese momento capacidad de discernimiento. No se trata de que la acción sea moralmente ilícita, pero el sujeto que la realiza se halle bajo unas condiciones que excluyan su culpabilidad moral. Se trata de ponerle una excepción a la regla; mejor dicho, de construir una sub-regla que excepciona a la otra, a la general, para un supuesto especial. Exactamente igual que, en lo jurídico, la regla sobre la legítima defensa excepciona a la regla que prohíbe y castiga el homicidio.

Solamente así tiene sentido la discusión sobre el carácter absoluto de aquella prohibición. Porque si admitimos que no caben justificaciones, sino "excusas" subjetivas, en realidad estamos dando por buena la naturaleza absoluta de la regla prohibitiva. Por eso hay una cierta petición de principio en la tesis de Davis, ya que si nos empeñamos en que las razones que aportan los que consideran racional la

77 M. Davis, "The Moral Justifiability of Torture and other Cruel, Inhuman, or Degrading Treatment", International Journal of Applied Philosophy, 19, 2005, p. 172. 
excepción a la prohibición en ciertos casos no son calificables como razones en favor de una justificación para un supuesto, para ciertos hechos, sino como razones para la concurrencia de una eximente por falta de culpabilidad subjetiva, damos por sentada la verdad de lo que queríamos demostrar: que la prohibición moral de la tortura tiene excepciones moralmente justificadas.

\section{6. "Moral luck"}

En el ejemplo de la ticking bomb, con sus muchas variantes, no sólo se asume el cumplimiento de determinadas condiciones epistémicas (se sabe con certeza que...) y prácticas (se tortura solamente en la estricta medida necesaria para..., no hay elementos de sadismo o ensañamiento, etc.), sino que, según algunos críticos, se da implícitamente por sentado que el extraordinario y noble objetivo se alcanza y, por tanto, el torturado confiesa dónde está la bomba y esta puede ser desactivada, aquellas potenciales víctimas inocentes salvadas, etc. Algún autor se ha preguntado qué sucede si en nuestro razonamiento incorporamos la innegable posibilidad de que la tortura no rinda esos resultados porque, aunque aquellas condiciones epistémicas y prácticas se cumplan, sencillamente el torturado, por muy culpable que sea, no proporcione la información buscada, porque no quiso darla y aguantó el dolor. Entonces el mal enorme que la tortura implica se habría consumado, pero para nada, a cambio de nada, sin consecuencias positivas que lo compensen.

La noción de "moral luck" fue introducida en la teoría ética por Thomas Nagel en 1976, en su artículo así titulado, "Moral Luck". Se trata de lo siguiente. Pongamos que dos conductores van por la misma carretera y conduciendo con el mismo grado muy alto de imprudencia. Pero cuando uno pasa hay un peatón cruzando y ese conductor, que a esa velocidad altísima no puede parar, lo mata. En cambio, al otro conductor no se le cruza nadie y termina su recorrido sin causar daño. La acción de los dos conductores al conducir parece igual de reprochable, pero a uno se le van a hacer normalmente mayores reproches porque mató a alguien, pese a que ese diferente resultado no se corresponde con un grado diferente de reprochabilidad de las acciones, sino que es consecuencia del puro azar, de la suerte, de un factor fuera del control de esos dos sujetos. Esto pone en serias dificultades a la teoría moral, pues, como originariamente expuso Nagel, nos enfrenta al siguiente dilema: 0 bien consideramos que la responsabilidad moral de las personas es solamente por lo que está efectivamente bajo su control, con lo que la responsabilidad moral de aquellos dos conductores es idéntica, al margen de que uno haya causado efectivamente la muerte de un peatón inocente; 0 bien, a la hora de evaluar la responsabilidad moral de cada uno, introducimos como relevantes componentes no dependientes 
del control efectivo sobre las consecuencias de la propia conducta, sino dependientes de la suerte.

Nathan Stout, en su artículo "Ticking Bombs and Moral Luck: An Analysis of Ticking Bomb Methodology"79 ha pretendido usar esa idea para criticar la posible justificación moral de la tortura en los casos de la bomba. Presenta primeramente un caso del siguiente estilo. Se sabe que un terrorista ha puesto la fatídica bomba y que dicho terrorista es uno de los cien habitantes de cierto edificio. No hay manera de saber cuál de los cien será, así que se decide al azar torturar a uno de esos cien, de los cuales, como se ha dicho, noventa y nueve son inocentes. Se pregunta Stout si consideraríamos que estaría moralmente justificada esa tortura de uno al azar y con tanta probabilidad de que sea un inocente, o si lo pensaríamos así si se da la gran casualidad o hay la gran suerte de que el torturado sea precisamente el terrorista y este confiesa a tiempo. Le parece a Stout que en ningún caso tendría tal tortura justificación y que eso no cambia en función de la suerte en el resultado. Es decir, que ese buen resultado, si hay gran suerte, no convierte en buena la acción mala.

Pero podríamos preguntarnos nosotros esto: ¿qué es lo que, en ese caso, hace particularmente inmoral la tortura? Y la respuesta creo que sería así: el asumir la tortura de inocente, aunque el azar puede hacer que sea culpable el torturado. De ese modo se ha cambiado uno de los presupuestos epistémicos del ejemplo de la bomba, como es la certeza de que el sujeto para el que se plantea la tortura es culpable y puede decir a tiempo dónde está la bomba.

Según Stout, aun en el ejemplo típico de la bomba y con sus presupuestos epistémicos, puede de hecho suceder que la tortura tenga éxito o que no, en cuyo caso se ha torturado al culpable, pero no se ha evitado el desastre para las víctimas inocentes. Eso no está bajo el control del torturador, ahí hay también un elemento de azar o suerte. Si en el ejemplo anterior la suerte no cambiaba el carácter inmoral de la acción, en este otro caso tampoco podrá cambiarlo, y la tortura tanto será inmoral si por azar tuvo éxito como si no lo tuvo. Porque si sólo respondemos moralmente por lo que está bajo nuestro control, respondemos por torturar y torturar está siempre mal, se salven aquellas vidas o no se salven.

Creo que el razonamiento de Stout es erróneo. Al cambiar el contenido de los ejemplos y los presupuestos de cada uno, modifica un aspecto esencial. Lo que hace que su ejemplo primero provoque el mayor rechazo moral es que se asume en él la tortura de inocentes como altísimamente probable, mientras que en el ejemplo de la bomba, y dadas sus condiciones epistémicas, por definición se descarta tal cosa. La 
"suerte" en el caso estándar de la bomba no depende de que el torturado sea o no el culpable y pueda de hecho o no dar la información buscada. El culpable sí es él, y el que proporcione o no dicha información depende de su voluntad. Así que en los dos ejemplos, en efecto, hay un factor de "suerte" que no está bajo el control pleno del que tortura, pero en el ejemplo estándar o habitual el resultado sí está bajo el control del "malo", que por definición no es inocente. La suerte no juega ahí para determinar si el torturado va a ser un inocente o el culpable, sino para determinar si el culpable va a confesar a tiempo o no. Desde la perspectiva del que tortura se trata de "luck", pero desde el punto de vista del torturado no es "luck", es propósito deliberado de que se produzca el mal que ansía y perseverancia en ese propósito pese a la tortura.

Regresemos al ejemplo típico de los dos conductores que van a velocidad imprudente y comparemos dos situaciones. Uno de los conductores atropella y mata a alguien que cuidadosamente y en su derecho cruzaba por un paso de peatones 0 un semáforo. El otro atropella y mata a alguien que con ánimo suicida se ha arrojado a la calzada a su paso. La culpa de la víctima tendría relevancia en un razonamiento jurídico y posiblemente debería tenerla también en un razonamiento moral como el que aquí nos interesa, aunque la suerte haya determinado el resultado diferente para dos conductores cuya acción era igualmente imprudente.

\subsection{La bomba puede acabar estallando de todos modos}

En uno de los más profundos y más citados trabajos de crítica al argumento de la ticking bomb, Vittorio Bufacchi y Jean Maria Arrigo apuntan que es falaz el razonamiento cuando se presupone como elemento básico que el terrorista torturado dará la información que se le exige y de ese modo se podrá desactivar la bomba. Como empíricamente eso no se puede saber con total certeza, decae la justificación finalística de la tortura en esos supuestos ${ }^{80} .0$ sea, si se justifica torturar porque se sabe que el criminal va a dar la información, pero resulta que no es verdad que se sepa que va a darla, es falso que esté justificado torturar.

Ciertamente, ese no puede ser uno de los presupuestos epistémicos del caso, creo. En verdad Bufacchi y Arrigo ponen en tela de juicio todos los presupuestos epistémicos de carácter empírico, pero me parece que aquítiene sentido concentrarse en este. La pregunta sería así: ino estaría jamás moralmente justificada la tortura a no ser que fuera plena la certeza empírica de que va a tener éxito y se va a lograr del criminal la vital información buscada? Considero que esto no es así.

80 V. Bufacchi, J.M. Arrigo, "Torture, Terrorism and the State: a Refutation of the Ticking Bomb Argument", cit., pp. 360ss. 
Pensemos un caso para comparar. Un vecino mío es perseguido por un asesino que lo quiere matar. Yo veo pasar corriendo a mi vecino, que, en una bifurcación, toma el camino A. Al poco aparece su perseguidor, que me pregunta por dónde ha ido el otro. Yo le miento y le digo que huyó por el camino B. Ciertamente, hay el riesgo de que el asesino perseguidor no me crea, pero si mi mentira puede estar moralmente justificada, lo estará aunque yo al mentir no tenga el conocimiento seguro de que el asesino me va a creer y voy a lograr así salvar al mi pobre vecino.

Por la misma razón, creo que, presupuestas a modo de hipótesis las otras circunstancias epistémicas, no es necesario presuponer el éxito de la tortura del culpable para que esté moralmente justificada. La justificación está en intentarlo, no en conseguirlo. A no ser, claro, que seamos absolutistas morales tanto en el caso de la mentira (al kantiano modo) como en el de la tortura. Pero si somos absolutistas morales, las condiciones epistémicas en realidad nada importan, pues partimos, a modo de axioma incontestable, de que la acción es moralmente injustificable tanto si las condiciones son unas como si son cualesquiera otras; es decir, ni en condiciones reales ni bajo condiciones ideales admitiremos la justificación moral de ninguna tortura y para nada.

\section{Bibliografía}

Allhoff, Fritz, "Ticking Time-Bombs and Torture", en Contemporary Debates in Applied Ethics, A.I. Cohen, Chr. H. Wellman, 2a ed., Wiley, 2014.

Allhoff, Fritz, "Torture Warrants, Self-Defense, and Necessity", Public Affairs Quarterly, 25, 2011.

Allhoff, Fritz, Terrorism, Ticking Time-Bombs and Torture. A Philosophical Analysis, Chicago, The University of Chicago Press, 2012.

Ambos, Kal, Terrorismo, tortura y Derecho penal. Respuestas en situaciones de emergencia, Barcelona, Atelier, 2009.

Anscombe, G.E.M., “Modern Moral Philosophy”, Philosophy, 33, nº 124, 1958.

Blackburn, Pierre, La ética. Fundamentos y problemáticas contemporáneas, México, Fondo de Cultura Económica, trad. J.J. Utrilla Trejo, 2006.

Brecher, Bob, Torture and the Ticking Bomb, Oxford, Blackwell, 2007.

Bufacchi, Vittorio, Arrigo, Jean Maria, "Torture, Terrorism and the State: a Refutation of the Ticking Bomb Argument", Journal of Applied Philosophy, 23, 2006.

Card, Claudia, "Thickinig Bombs and Interrogations", Criminal Law and Philosophy, 2008. 
Davis, Michael, "The Moral Justifiability of Torture and other Cruel, Inhuman, or Degrading Treatment", International Journal of Applied Philosophy, 19, 2005. Exortación Apostólica Post-Sinodal Reconciliatio et Paenitentia, de Juan Pablo II, 1984, apartado 17.

FinNIs, JoHn, Absolutos morales, Barcelona, Ediciones Internacionales Universitarias, 1991, trad. de J.J. García Norro.

GRECO, LuIs, "Las reglas detrás de la excepción. Reflexiones respecto de la tortura en los grupos de casos de las ticking time bombs", In Dret, abril de 2007.

Greer, Steven, "Is the Prohibition against Torture, Cruel, Inhuman and Degrading Treatment Really 'Absolute' in International Human Rights Law?", Human Rights Law Review, 15, 2015.

Gross, Oren, "The Prohibition on Torture and the Limits of Law", en Torture. A Collection, Sanford Levinson, Oxford, Oxford University Press, 2004.

Hilgendorf, Eric, "Folter im Rechtsstaat?", Juristen Zeitung, 2004.

Holmes, Stephen, "Is Defiance of Law a Proof of Success? Magical Thinking in the War on Terror", en Karen J. Greenberg, The Torture Debate in America, Ney York, Cambridge University Press, 2005.

JäGER, Christian, "Das Verbot der Folter als Ausdruck der Würde des Staates", en Strafrecht zwischen System und Telos. Festschrift für Rolf Dietrich Herzberg zum siebzigsten Geburtstag, Tübingen, Mohr Siebeck, 2008.

Kamm, Frances. M., Ethics for Enemies. Terror, Torture and War, New York, Oxford University Press, 2011

Levinson, Sanford, "Contemplating Torture. An Introduction", en Torture. A Collection, Oxford University Press, 2004

Llobet Anglí, Mariona, "iEs posible torturar en legítima defensa de terceros?", InDret, 2010.

LuBAn, DAVID, "Liberalism, Torture, and the Thicking Bomb", en The Torture Debate in America, Karen J. Greenberg, Ney York, Cambridge University Press, 2005. Luban, David, "Unthinking the Ticking Bomb", en Global Basic Rights, Ch.R. Beitz, R. E. Goodin -eds.- Oxford University Press, 2011.

Luban, David, "Unthinking the Ticking Bomb", en: Ch.R. Beitz, R. E. Goodin -eds.Globan Basic Rights, Oxford University Press, 2011.

McDonald, Catherine, "Deconstructing Ticking-Bomb Arguments", Global Dialogue, 12, 2010. 
McMahan, Jeff, "Torture and Method in Moral Philosophy", Torture, Law, and War, Scott Anderson and Martha Nussbaum, eds., Chicago, University of Chicago Press, 2016.

Mendus, Susan, "Professor Waldron Goes to Washington", Criminal Law \& Philosophy, 8, 2014, p. 125.

Mitsch, Wolfgang, "Verhinderung lebensrettender Folter", en Strafrecht als Scientia Universalis. Festschrift für Claus Roxin zum 80. Geburtstag am 15. Mai 2011, Berlín, de Gruyter, 2011.

Molina Fernández, Fernando, “La ponderación de intereses en situaciones de necesidad extrema: ¿es justificable la tortura?", en La respuesta del Derecho penal ante los nuevos retos, A. Cuerda Riezu -dir.-, Madrid, Dykinson, 2006.

Prittwitz, Cornelius, "Strafwürdigkeit und Strafbarkeit von Folter und Folterandrohung im Rechtsstaat", en Strafrecht zwischen System und Telos. Festschrift für Rolf Dietrich Herzberg zum siebzigsten Geburtstag, Tübingen, Mohr Siebeck, 2008.

Roxin, Claus, “El nuevo desarrollo de la dogmática jurídico-penal en Alemania”, InDret, octubre de 2012.

Roxin, Claus, Culpabilidad y prevención en Derecho penal, Madrid, Reus, 1981, traducción de F. Muñoz Conde.

Roxin, Claus, “Kann staatliche Folter in Ausnahmefällen zulässig oder wenigstens straflos sein?", en Menschengerechtes Strafrecht. Festischrift für Albin Eser zum 70. Geburtstag, München, Beck, 2005

Shue, Henry, "Torture in Dreamland: Disposing of the Ticking Bomb", Case Western Reserve Journal of International Law, 37, 2006.

Shue, Henry, "Torture", en Torture. A Collection, Sanford Levinson (ed.), Oxford University Press, 2004.

Stout, Nathan, "Ticking Bombs and Moral Luck: An Analysis of Ticking Bomb Methodology", Human Rights Review, 12, 2011.

Sussman, David, “What's Wrong with Torture?", Philosophy \& Public Affairs, 33, 2005. Thomson, Judith Jarvis, "Killing, Letting Die, and the Trolley Problem", en Ethical Theory. An Anthology, Russ Schafer-Landau (ed.), Blackwell, 2ª ed., 2013.

Tindale, Christopher W., "Tragic Choices: Reaffirming Absolutes in the Torture Debate", International Journal of Applied Philosophy, 19, 2005.

Waldron, Jeremy, "Responses to Zedner, Haque and Mendus", Criminal Law \& Philosophy, 8, 2014. 
Waldron, Jeremy, "What are moral absolutes like", Harvard Review of Philosophy, 18, 2012.

Waldron, Jeremy, Torture, Terror and Trade-Off. Philosophy for the White House, Oxford, Oxford University Press, 2010.

Walzer, Michael, "Dirty hands and ordinary life", Philosophy and Public Affairs, 2, 1972.

Wisnewski, Jeremy. J., Emerick, R.D., The Ethics of Torture, London/New York, Continuum, 2009. 